\title{
On The Eagle's Wings: Textiles, Trenton, and a First Taste of the Industrial Revolution
}

\author{
Richard W. Hunter, Nadine Sergejeff and Damon Tvaryanas ${ }^{1}$
}

\begin{abstract}
This paper relates the rise, fluctuating fortunes and eventual fall of the Eagle Factory, Trenton's first major textile manufacturing enterprise, located on the Assunpink Creek in the heart of New Jersey's capital city. Established in 1814 at the dawn of the American Industrial Revolution and controlled throughout by the Walns, a prominent Quaker merchant family of Philadelphia, the Eagle Factory began by producing yarns and hand-woven goods. Following the introduction of power looms in the 1820s the factory shifted into the mass production of a variety of machine-made fabrics, including plaids, checks, muslin, gingham, ticking and number of more distinctive cloths. However, this strictly family-run enterprise was never entirely successful, falling victim to broader global economic forces and regional competition, as well as several floods and fires. The plant closed altogether following a devastating fire in 1845 . In tracing the checkered history of the Eagle Factory, liberal use is made of the letter book of Lewis Waln and the Waln family papers at the Historical Society of Pennsylvania, as well as insurance records, newspaper advertisements and land records.
\end{abstract}

Trenton's roots as an industrial city generally are traced to the manufacture of iron, steel and pottery, and to the entrepreneurial efforts of well-known individuals like Peter Cooper, Abram S. Hewitt, John A. Roebling, Thomas Maddock, John Hart Brewer and Walter Scott Lenox in the mid to late nineteenth century. The city's true industrial beginnings, however, can be found in the 1810s, when a less-visible group of craftsmen, merchants and investors sought to participate in the emerging domestic manufacturing sector, jolted into action when the War of 1812 curtailed trade from abroad. The textile industry was in the forefront of this surge to establish manufacturing facilities in Trenton, and many other cities along the eastern seaboard. Following the lead of British technology, American cotton and woolen manufacturers rapidly pursued the introduction of a factory system during this period, mechanizing and integrating spinning, carding, and weaving processes, building up a skilled labor pool that drew on women and children as well as men, and developing complex and wide-ranging networks for the importation of raw materials and distribution of finished goods.

Today, the crudely landscaped, grassy swale that denotes the culverted course of the Assunpink Creek between South Broad and South Warren Streets offers no reminders of

\footnotetext{
${ }^{1}$ Richard Hunter is President of Hunter Research, Inc. a Trenton-based historical resource consulting firm founded in 1986. He has a Ph.D. in geography from Rutgers University and wrote a dissertation on the historical geography of water-powered mills in central New Jersey. Damon Tvaryanas is Principal Historian/Architectural Historian at Hunter Research and holds an M.S. from the University of Pennsylvania in Historic Preservation. Nadine Sergejeff, a reference and collections librarian at Newark Public Library with an MLIS from Rutgers University, formerly served as Historian at Hunter Research.
} 
the profusion of industrial enterprise that once lined the stream banks in this section of downtown Trenton (Figure 1).

Here, midway through the 1810 s, the city's first concerted foray into the Industrial Revolution occurred, and two of the earliest large-scale textile manufacturing ventures in the Delaware Valley took root. Just below South Broad Street, on the south bank of the creek, rose a massive five-story brick cotton mill, the centerpiece of the Eagle Factory (Figure 2). Immediately adjacent and downstream, a second, slightly smaller three-story cotton mill, that of the Trenton Manufacturing Company, was erected at around the same time on land leased from the owners of the Eagle Factory.

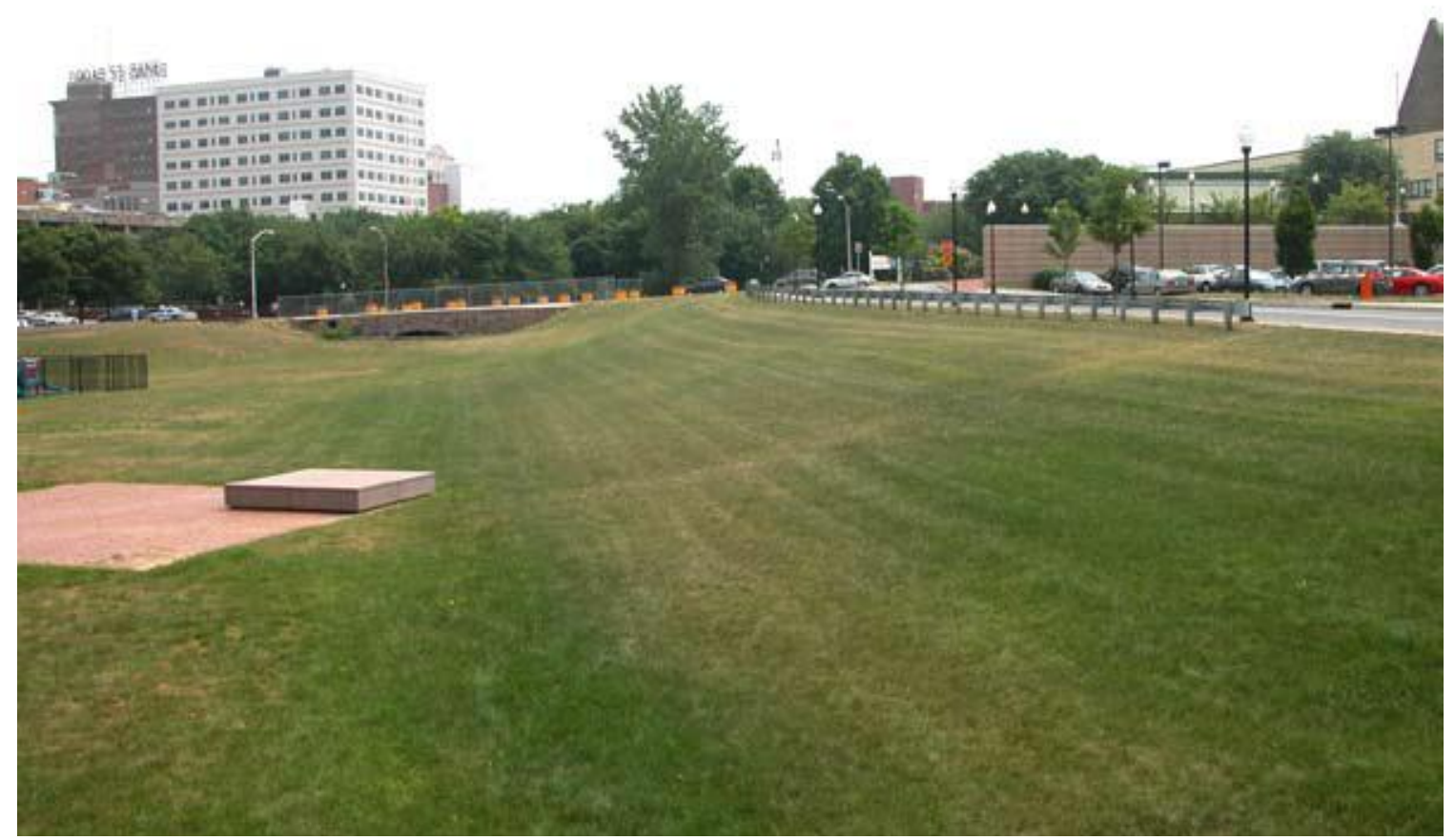

Figure 1. View looking northeast from South Warren Street towards the South Broad Street crossing of the Assunpink Creek in 2003. The grassy swale covers the filled and culverted creek. The sites of the Eagle Factory and Trenton Manufactory are beneath the grassy bank in the center of the view.

The Eagle Factory, so named for that avian emblem of American commercial and industrial vigor in the early years of the republic, was founded on the wealth of the Walns, a family of prominent Philadelphia Quaker merchants. At its peak, this industrial complex included a nearby gristmill, remodeled for picking and cleaning cotton; a pair of weaving mills equipped with power looms; and the factory building itself, which was constructed of brick. All of these industrial operations were hydropowered, drawing water from the Assunpink. Various related workshops, storehouses, sheds, a factory store and an office were scattered elsewhere across the Eagle property. The Eagle Factory expanded production quickly at first, helped by the federal government's imposition of tariffs on imported manufactured goods, but eventually fell victim to the fluctuating economic trends brought about by regional and global competition. Flooding on the 
Assunpink and occasional fires further constrained the operations of both the Eagle and the Trenton Manufacturing Company cotton mills. After a generation of mixed profitability, the Eagle Factory shut down after a particularly devastating fire in 1845 , with the Waln family finally selling off the mill property in 1849 . The Trenton Manufactory survived past midcentury, after which it was reconfigured and expanded as a woolen mill that continued in operation into the twentieth century (Figure 3).

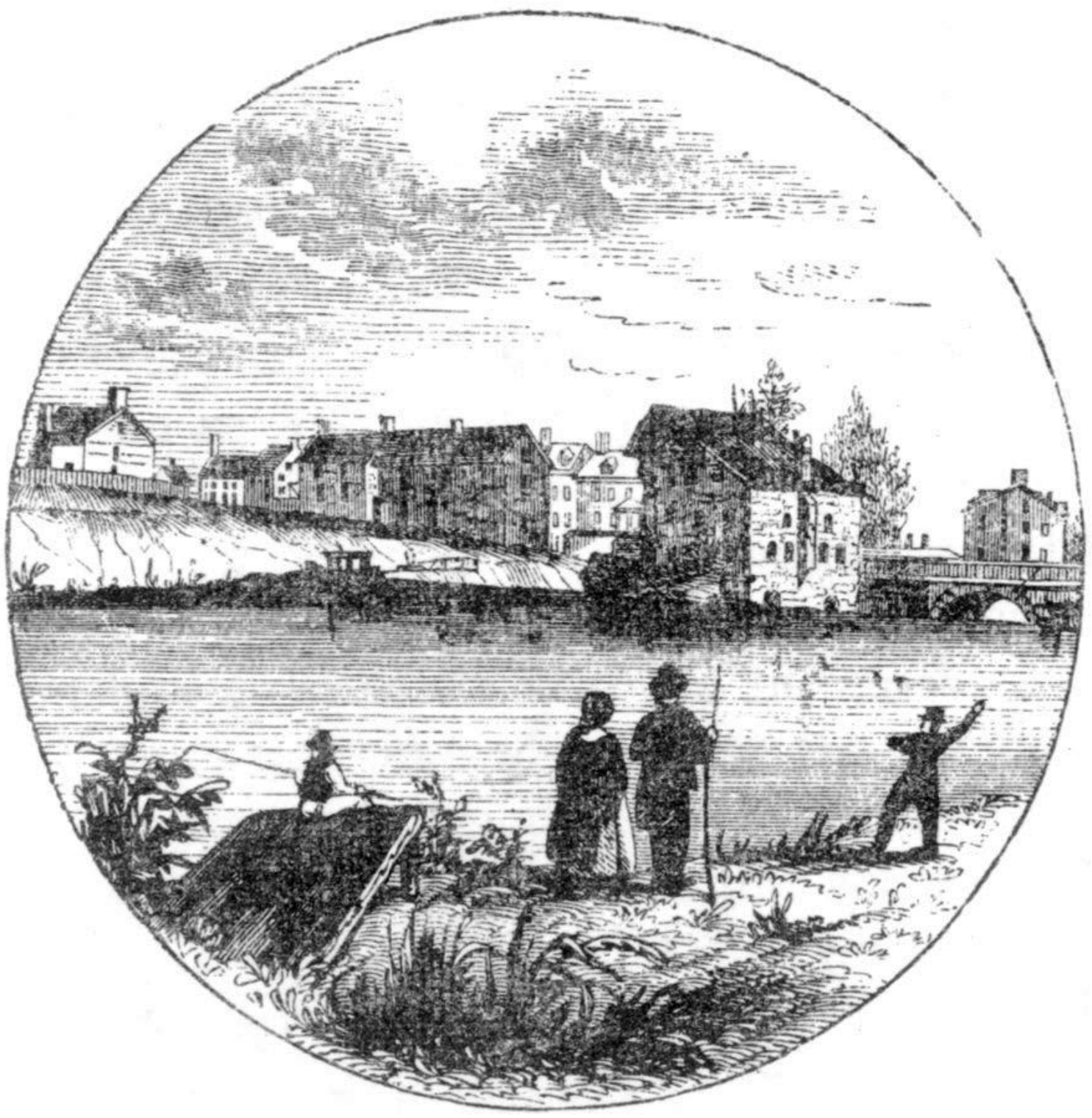

Figure 2. "Trenton Bridge and Vicinity." (Benson J. Lossing, Pictorial Field Book of the Revolution, Volume II [Harper \& Brothers, New York, 1850]). This view, drawn in November 1848, looks southwest from the north bank of the Assunpink Creek across the millpond toward the South Broad Street bridge. The Eagle Factory is the building at the far right below the bridge, while in the right center is the old gristmill used for picking and cleaning cotton. Between the two, the roof of one of the two Eagle weaving mills is just visible. 


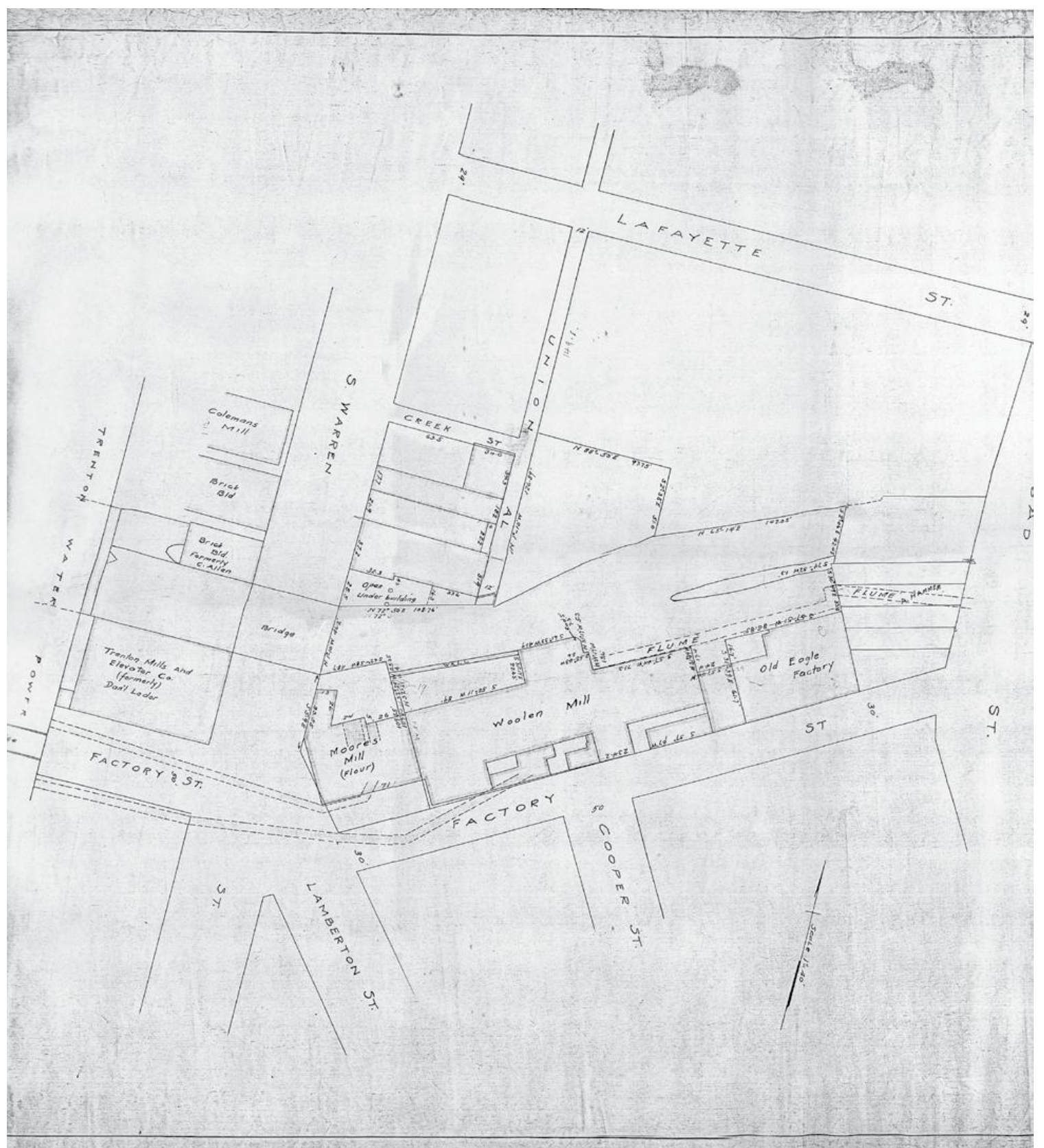

Figure 3. Map of the Assunpink Creek between South Broad and South Warren Streets in downtown Trenton. Circa 1905. Scale 1 inch: 120 feet (approximately). (City of Trenton Engineering Department).

This article focuses primarily on the Eagle Factory, the more dominant of the two cotton mills on the Assunpink, and aims to place this little-known facility within the broader context of Trenton's early industrial history, the emerging domestic textile manufacturing sector, and the Industrial Revolution in America. ${ }^{2}$ The initial impetus for this study was

\footnotetext{
${ }^{2}$ There are several standard sources that deal with the history of Trenton, but none of them coherently narrate the long sequence of water-powered industry along the Lower Assunpink. See John O. Raum, History of the City of Trenton (Trenton: W.T. Nicholson \& Co., 1871); Trenton Historical Society, $A$ History of Trenton, 1679-1929: Two Hundred and Fifty Years of a Notable Town with Links in Four Centuries (Princeton: Princeton University Press, 1929); Mary Alice Quigley and David E. Collier, A
} 
provided by a review of the letter book of Lewis Waln and other Waln family papers held by the Historical Society of Pennsylvania in Philadelphia. Lewis Waln, a son of Robert Waln, the founder of the Eagle Factory, was involved in management of the cotton mill from its earliest days and was sole owner of the business from 1829 until 1849. His letter book bears testimony to the daily rigors of operating a cotton mill: securing raw materials, dealing with management and labor issues, maintaining and insuring the physical plant, and establishing prices and markets for the manufactured goods. Along with other standard sources for this period, such as census data, deeds and mortgages, newspapers and historic maps, the Waln archive provides a rich lode of documentary material about the early years of textile manufacture in the Delaware Valley.

The Eagle Factory and its owners were in the vanguard of this industrializing movement in the Middle Atlantic region and were largely responsible for Trenton's first tentative steps toward becoming a major East Coast manufacturing center. Waln family capital, derived from colonial and early federal period mercantile activity, underwrote most of Trenton's initial progress in cotton production, and built the Eagle Factory complex while leasing land and water power to the neighboring Trenton Manufacturing Company and other milling operations. With the scale and multi-faceted aspects of their industrial development venture, the Walns in effect strove to graft a "factory village" on to the market town and capital city of Trenton, albeit without seriously assuming the role of supplying workers' housing.

For a generation or so, from 1815 into the mid-1840s, Trenton thrived as a center of Middle Atlantic textile production. With the help of protective tariffs, the production of cotton goods at the Eagle and Trenton Manufacturing Company mills was sustained through the 1820s and early 1830s, even though prices of cotton fiber and fabric were in overall decline. The completion of the Trenton Delaware Falls Company's power canal system in 1834-35 spurred construction of a new batch of textile-based manufacturing facilities, but the economic depression of the late 1830s and early 1840 s quickly dampened this growth. When recovery came in the mid-1840s, Trenton turned its focus instead to ironworking, and the few surviving textile mills began to concentrate instead on woolen manufacture.

Capital Place: The Story of Trenton (Trenton: Trenton Historical Society, 1984). Grain processing took place here from the late 1670s into the early twentieth century, involving three different sites during the nineteenth century; ironworking flourished briefly in the early eighteenth century; paper manufacture commenced in the late eighteenth century and continued intermittently into the late nineteenth century. From the early 1830s into the early twentieth century, the Trenton Water Power stimulated a further concentration of industrial activity along the Lower Assunpink, even though its water was drawn from the Delaware River six miles upstream from the downtown. The importance of early-nineteenth-century textile manufacture along the Lower Assunpink resurfaced as a result of a series of three cultural resource studies performed by Hunter Research, Inc. and reported as follows: "The Assunpink Creek in Mill Hill: A History and Consideration of Historic Interpretive Opportunities" (report prepared for the Old Mill Hill Society, 2002); "South Broad Street Bridge Cultural Resource Assessment, City of Trenton, Mercer County, New Jersey" (report prepared for the New Jersey Department of Transportation and the Federal Highway Administration, 2003); and "Phase IA Cultural Resources Investigation, Lower Assunpink Environmental Restoration Project, City of Trenton, Mercer County, New Jersey" (report prepared for the U.S. Army Corps of Engineers, Philadelphia District, 2003). 


\section{The Genesis of the Cotton Industry in America}

During the final two decades of the eighteenth century, US politicians, merchants and industrialists recognized the need for a strong domestic manufacturing base, particularly textile and metal production. ${ }^{3}$ From an American perspective, profitable textile manufacturing was necessary to clothe and provide work for the country's rapidly growing population and to nourish trade within the country and beyond. By the late 1780 s and early 1790s, British textile producers were far more advanced in the mass production of cotton cloth than their American counterparts and were beginning to monopolize United States and global markets. By 1788 no less than 150 water-powered cotton mills were in operation in Britain, most engaged in carding and spinning. The United States had none. ${ }^{4}$

American industrialization of cotton manufacture began in the early 1790s and evolved out of important developments in both the initial processing of raw material on cotton plantations and the realm of manufacturing. Crucial, of course, was Eli Whitney's invention in 1793 of the cotton "gin," a boxed revolving cylinder with spiked teeth that separated the bast fiber from the seeds, hulls and other material that make up the cotton plant. Initially driven by a hand-operated crank, but soon horse-powered and waterpowered, Whitney's invention permitted substantially greater quantities of cotton to be shipped from Southern plantations to cotton mills in the emerging industrial centers of Europe, New England and the Middle Atlantic.

The mechanization of cotton manufacture in the United States followed a pattern of technological, socio-economic and geographical development that was broadly similar to

and strongly influenced by that in Britain. ${ }^{5}$ Mechanization in the United States began a decade or two later than in Britain, but it spread rapidly, even though in some locations, like Paterson, New Jersey, the move toward integrating processes within a single building was much slower. The overall sequence of industrial development, however, was compressed into a shorter time frame, so that by the mid nineteenth century, cotton manufacturing on both sides of the Atlantic had attained a roughly equivalent level of technological competence and scale of operation.

\footnotetext{
${ }^{3}$ Albert Gallatin, Report from the Secretary of the Treasury, on the Subject of American Manufactures, Prepared in Obedience to a Resolution of the House of Representatives, April 19, 1810 ... (Boston, 1810); Jacob E. Cooke, Tench Coxe and the Early Republic (Chapel Hill: University of North Carolina Press, 1978).

${ }^{4}$ T.S. Ashton, The Industrial Revolution, 1760-1830, rev. ed. (Oxford: Oxford University Press, 1964); R. Angus Buchanan, Industrial Archaeology in Britain (London: Book Club Associates, 1974), 125-147; Terry S. Reynolds, Stronger than a Hundred Men: A History of the Vertical Water Wheel (Baltimore: Johns Hopkins University Press, 1983), 325-339; Clifford J. Lines, Companion to the Industrial Revolution (New York: Facts on File, 1990); Thomas Dublin, Lowell: The Story of an Industrial City (Washington, DC: National Park Service, 1992), 22-23.

5 David Jeremy, Transatlantic Industrial Revolution: The Diffusion of Textile Technology, 1790-1830 (Cambridge: MIT Press, 1981).
} 
A group of Philadelphians under the inspiration of the merchant and political economist Tench Coxe founded the Pennsylvania Society for the Encouragement of Manufactures and the Useful Arts in 1787. Society members were acutely interested in cotton manufacture as a potential source of economic development. Using inadequately understood sketch plans and models, they drew up plans for a cotton mill and erected a building, but financial difficulties, a disastrous fire, and the owners' poor grasp of operational requirements derailed the project in 1790. Coxe, by this time an assistant to Treasury Secretary Alexander Hamilton, decided to gather information about British cotton-manufacturing technology and set about luring mechanics with the necessary know-how to the United States. ${ }^{6}$ This effort, which at times bordered on industrial espionage, led to the introduction of Richard Arkwright's cotton spinning technology in the United States in the early 1790 s.

Despite British controls on the export of machinery and the emigration of skilled cotton workers and millwrights, Samuel Slater, an English mill overseer familiar with the Arkwright textile production system, succumbed to the temptation of American bounties offered for the introduction of cotton manufacturing technology. Arriving in New York late in 1789, Slater moved to Rhode Island in January of the following year at the urging of Moses Brown, a wealthy Quaker merchant in Providence. By December of 1790, Slater had recreated from sketches and his own experience a range of carding, drawing, roving and spinning machinery sufficient to attract American investors. In 1792-93, he built the first successful cotton mill in America on the Blackstone River in Pawtucket, Rhode Island with the backing of the Providence merchant firm of Almy \& Brown. ${ }^{7}$

Tench Coxe, meanwhile, used his experience with the Pennsylvania Society for the Encouragement of Manufactures and the Useful Arts to prevail upon Hamilton and other leading New Yorkers to launch another high technology initiative in 1791, known as the Society for Establishing Useful Manufactures (S.U.M.). An ambitious scheme was soon hatched for large-scale cotton manufacture based around the water power available at the Great Falls of the Passaic River. In addition, Coxe envisioned an entirely new industrial town, not unlike Robert Owen's model industrial settlement of New Lanark. Although the Great Falls venture initially foundered for want of capital and questionable management, the seeds were sown for the growth of Paterson as a textile-producing center. $^{8}$

By 1810, more than 60 cotton mills turning more than 30,000 spindles were in operation in the United States, with particular concentrations of textile manufacture in Rhode Island and in Philadelphia and the Delaware Valley. Industrial operations in cotton factories

\footnotetext{
${ }^{6}$ Cooke, Tench Coxe and the Early Republic, 83-108; Thomas M. Doerflinger, A Vigorous Spirit of Enterprise: Merchants and Economic Development in Revolutionary Philadelphia (Chapel Hill: University of North Carolina Press, 1986), 330-331.

${ }^{7}$ Gary Kulik, Roger Parks and Theodore Z. Penn, The New England Mill Village, 1790-1860 (Cambridge: MIT Press, 1982), xxv, 55-99.

${ }^{8}$ James B. Kenyon, Industrial Localization and Metropolitan Growth: The Paterson-Passaic District (Chicago: University of Chicago Press, 1960), 24-29; Louis C. Hunter, A History of Industrial Power in the United States, 1780-1930, Volume One: Waterpower in the Century of the Steam Engine (Charlottesville: University of Virginia Press, 1979), 208-209.
} 
during this period were mostly limited to carding and spinning. Weaving was usually done inside households on handlooms and on consignment; other late-stage processes such as bleaching and calico printing were also conducted in separate establishments outside mills. ${ }^{9}$

From 1807 through the War of 1812, successive American embargoes on foreign goods, intended to force an end to restrictive British and French trading practices, cut off the United States from much of its profitable foreign trade and closed the door to imported British textiles. The harsh reality of potential clothing shortages, unused merchant capital, and idle ships in the East Coast ports of Boston, Providence, New York and Philadelphia, prompted a surge of American investment in domestic textile manufacturing enterprises. This led to a rapid increase in the number of cotton mills along the eastern seaboard, with most of these facilities still engaged chiefly in carding and spinning.

During the second decade of the nineteenth century, power loom technology - already known in England for a quarter of a century - finally made its way to the United States. The introduction of the power loom into American cotton mills, and its incorporation within the nation's emerging factory system, was primarily a result of the efforts of the prosperous Boston merchant Francis Cabot Lowell, who visited the Manchester area in England in 1810-11. By 1814, with the help of mechanic Paul Moody, Lowell succeeded in reproducing the power looms he had seen in England and, still more important, had integrated the three main cotton manufacturing processes - carding, spinning and weaving - under the same roof. These accomplishments set the stage for the creation of the mill town of Lowell on the Merrimack River in the early 1820s and the phenomenal growth of textile manufacturing in New England during the second quarter of the nineteenth century. The Waltham-Lowell system, as it became known, spread rapidly into the Middle Atlantic region, helping to revive the foundering mill town of Paterson in the 1820 s and 1830s and spurring several textile manufacturing ventures in the Delaware Valley, including the Eagle Factory in Trenton. ${ }^{10}$

\section{Trenton Textile Manufacture in the Early Nineteenth Century}

Trenton's first venture into industrialized textile manufacture was hardly a spectacular success. In 1812, Josiah Fithian, a cabinet maker living on Second (today's West State) Street, a few doors east of the State House, set about establishing a cotton factory on Petty's Run, a minor tributary of the Delaware River that flowed through his property. ${ }^{11}$

\footnotetext{
${ }^{9}$ Dublin, Lowell, 24-25; Phyllis Mount, "Early Calico Printing” in Rachel Cochran, Rita Erickson, Natalie Hart and Barbara Schaffer, eds., New Jersey Quilts 1777 to 1950 (Paducah, Kentucky: American Quilters Society, 1992), 27-33.

${ }^{10}$ Kulik et al., The New England Mill Village, xxvi; Dublin, Lowell, 30-35; L.R. Trumbull, A History of Industrial Paterson (Paterson, New Jersey, 1882); William Nelson, The Founding of Paterson as the Intended Manufacturing Metropolis of the United States (Newark: Advertiser Printing House, 1887).

${ }^{11}$ Raum, History of the City of Trenton, 234-235, reported several decades later that Fithian "had completed the walls, put on the roof, and was about putting in the machinery for a cotton mill, when a heavy rain undermined the foundation, and the mill fell with a terrible crash - a mass of ruins. He rebuilt it,
} 
With much borrowed capital, Fithian erected a mill on the north side of the Front Street crossing of Petty's Run on the site of an earlier water-powered plating mill and steel furnace (Figure 4). ${ }^{12}$ By 1819, Fithian was in financial difficulty and ownership of the cotton mill property passed to his brother-in-law and creditor, Jacob Scudder. ${ }^{13}$ Scudder published a sale notice for the mill in 1819 , noting that the premises were "occupied by Mr. Gideon H. Wells," one of the partners in the Eagle Factory, although it is unclear if Wells was actually engaged in manufacturing on the site. ${ }^{14}$ No further mention of this cotton factory has been found in the documentary record and it would appear that it ceased operation around this time. Based on the technology available in the United States in 1812, the Fithian cotton manufacturing venture most likely involved the carding and spinning of yarn for local distribution to weavers using handlooms.

In the meantime, in 1814 and 1815, two larger and more durable cotton factories, along with a woolen factory, were built on the Assunpink Creek below Greene (modern South Broad) Street, roughly 1,000 feet to the southeast of the Fithian mill (Figure 4). The Eagle Factory was the larger of the two cotton manufacturing facilities. The other cotton mill was erected by Lawrence Huron \& Company immediately downstream of the Eagle Factory on land leased from Gideon Wells, brother-in-law of Robert Waln and his partner in the Eagle Factory. ${ }^{15}$ These two mills - the Eagle Factory and what soon became known as the Trenton Manufactory or the Trenton Cotton Factory - became closely intertwined. The latter was eventually owned by James Hoy, formerly a superintendent at the Eagle Factory, while the water power for this mill was for many years drawn from the same millpond that supplied the Eagle Factory and flowed through the Eagle Factory property. During this period, both the Trenton Manufactory and the Eagle Factory, like the Fithian cotton mill, most likely made use of water-powered machinery for picking, cleaning, carding and spinning in a minimally integrated fashion, and relied on workers using handlooms, probably both on- and off-site, for weaving. Power looms were introduced at the Eagle Factory by 1821 (and possibly earlier) and were present at the Trenton Manufactory before 1826, suggesting that these mills were influenced by the WalthamLowell system.

\footnotetext{
put in machinery and commenced the manufacture of cotton cloth. He continued here, however, but a short time, when he sold out to General Garret D. Wall, who converted it into a paper mill ..."

${ }^{12}$ Richard W. Hunter and Richard L. Porter, "American Steel in the Colonial Period," Canal History and Technology Proceedings 9 (1990): 83-118; Hunter Research, Inc., "Archaeological Investigations: Executive State House Parking Lot D Security Improvements, City of Trenton, Mercer County, New Jersey" (report prepared for the New Jersey Department of the Treasury, 2007).

${ }^{13}$ Hunter Research Associates, "Archaeological Investigations at the New Jersey State House," 5-22 to 526.

${ }^{14}$ Trenton Federalist, January 11, 1819.

${ }^{15}$ Burlington County Deed C-185.
} 


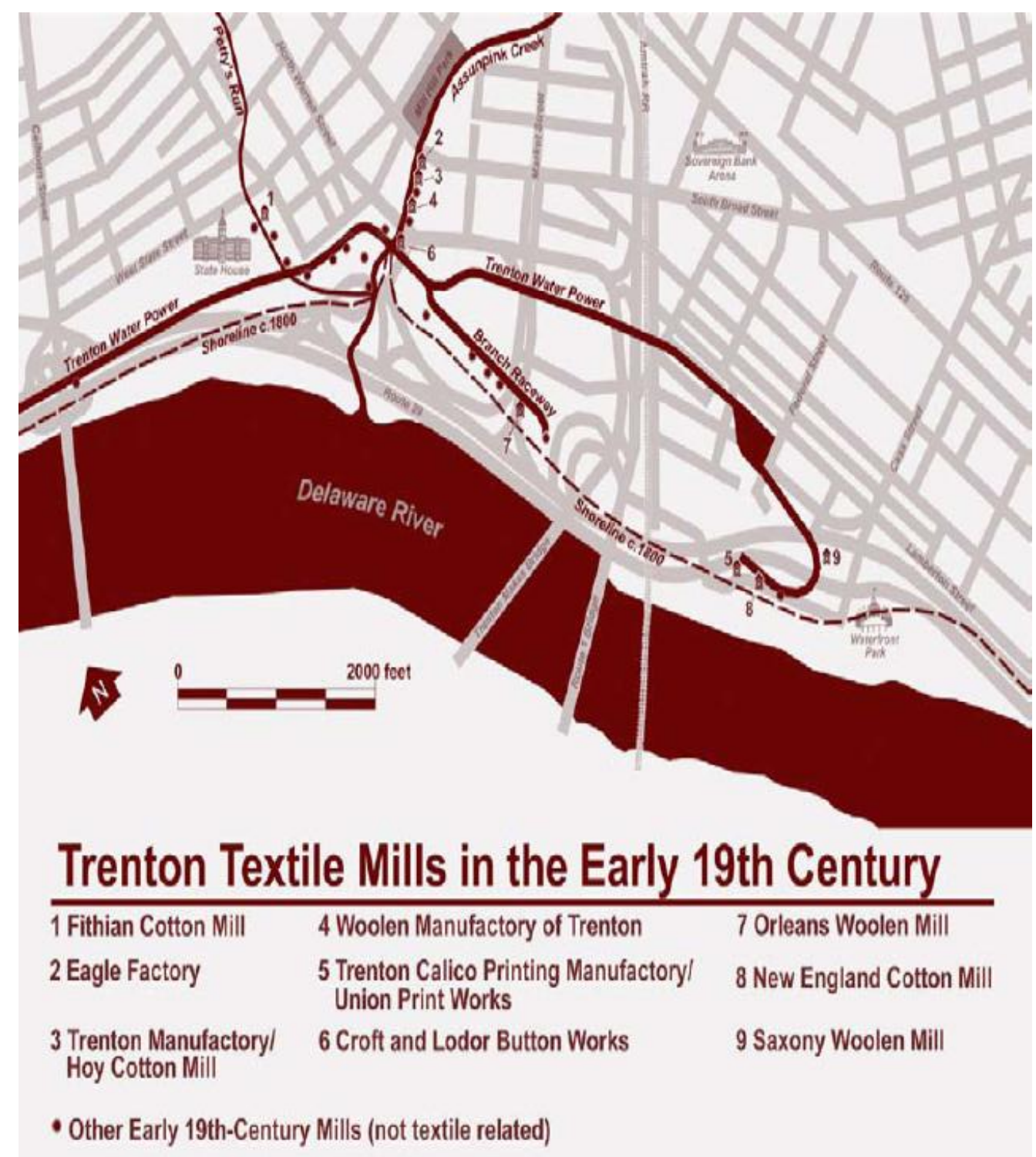

Figure 4.

The Trenton Manufactory, however, struggled during the 1820s. The mill and its machinery were subject first to a sheriff's sale and then a public auction in early 1826 . The notice for the sheriff's sale provides the first detailed information about this factory, describing a three-story brick building, 80 by 40 feet in plan, which included a dye house and blacksmith shop in addition to a range of textile machinery that included four throstle (thread-spinning) frames, stretchers, carding engines, eight power looms, two wrapping mills and two mules with 258 spindles. ${ }^{16}$

The 1833 federal manufacturing census reveals a subsequent upgrading of the weaving operations, noting along with other useful data that a steam-powered weaving shop had

\footnotetext{
${ }^{16}$ True American, March 11, 1826; Trenton Federalist, May 29, 1826.
} 
been established in $1829 .{ }^{17}$ Products were chiefly marketed in Philadelphia and sold by commission at six to eight months' credit, with 5 percent to 7.5 percent for commission and guarantee. The early 1830s clearly were a difficult time for textile mills and, as reflected in the census data, Hoy's operations produced little profit. When asked what he might do with his capital if forced to abandon his business following a lowering of tariffs on imported textiles, Hoy replied that he would employ his capital "in no other way, having none left. If I, who have been long in the business, would have to abandon it, who would purchase my property? It would be the most unproductive stock in the United States; I could not sell it." 18

The history and location of the third textile factory to emerge on the Assunpink in the 1810s are poorly understood. A series of newspaper notices between 1814 and 1816 refer to a mill seat that was initially developed for a woolen factory by John Denniston. ${ }^{19}$ Described as being located between one-quarter and one-half mile from the "market house," this mill is believed to have been situated downstream of the Trenton Manufactory and opened for business over the winter of 1814-15, offering to full, dye, and dress wool cloth (Figure 4). By the late spring of 1816, however, Ellett Tucker, a Greene Street storeowner, and Gideon H. Wells, the Eagle Factory partner, were attempting to sell off the mill equipment, which included carding, spinning and shearing machinery. The factory faded into obscurity after this time.

Just a few years after the founding of the three factories on the Assunpink, another important thread in Trenton's early-nineteenth-century textile industry emerged on the banks of the Delaware at the foot of Federal Street, about one-half mile downstream from the mouth of the Assunpink (see Figure 4). In 1817, a calico printing factory was erected there by John B. Sartori on his riverfront estate, a property centered on a fine federal

\footnotetext{
${ }^{17}$ The establishment was referred to in this census as "James Hoy's Trenton Cotton Factory." In response to the census taker's question in 1833: "what amount of the agricultural production of the country is consumed in your establishment, and what amount of other domestic productions?" Hoy listed "6,000 lbs. Flour, leather for belts, \&c., 800 lbs., coal 80 tons, wood 300 cords, shuttles 150, pickers 500, reeds 200, heddles 150 sets, 115,000 pounds cotton, besides iron and wood work, with sheep skins, glue, list, oil 800 galls., and indigo 2,000 lbs., and copperas and lime, and dye stuffs of most all descriptions; mostly all domestic manufactures." Production was given as: " 100,000 pounds of yarn valued at 17 to 60 cents per pound; 115,000 pounds of cotton at 32 to 10 [0] cents per pound; 500,000 yards of cloth at 10 cents a yard," with a note being added that "the great profit was enjoyed only a few years on spinning, at its commencement, and for the last 8 months." The labor force at the factory was composed of 32 men, paid $\$ 6$ a week, 80 girls, paid $\$ 3$ a week, and 68 children, paid $\$ 1$ a week. A 12-hour summer workday (reduced to 10 hours in winter) was imposed upon employees, and the children were allowed one quarter of the year for school, either in fall or spring. The annual wages totaled $\$ 26,000$ and the cost of materials to Hoy amounted to another $\$ 52,000$. The capital invested in the cotton spinning mill was given as $\$ 69,000$, and in the new weaving shop as $\$ 32,000$, while the water power used in the former facility (leased from Gideon Wells and Lewis Waln) required an annual payment of $\$ 600$. Hoy reported borrowing $\$ 20,000$ at a $6 \%$ rate of interest in support of the mills, and the profit on the un-borrowed portion of the investment was given as 3\% per annum. See Louis McLane, Documents Relative to the Manufactures in the United States, Collected and Transmitted to the House of Representatives (New York: Augustus M. Kelley, 1833), 164166.

${ }^{18}$ Ibid.

${ }^{19}$ Trenton Federalist, February 6, 1815; February 27, 1815; September 18, 1815; May 25, 1816; June 3, 1816.
} 
dwelling known as Rosey Hill. ${ }^{20}$ Sartori, the son of a jeweler to the Pope, was born in Rome and emigrated to Philadelphia in 1793. Best known as the first United States consul to the Vatican, an appointment he received in 1797 from President John Adams, Sartori lived at Rosey Hill from 1803 until 1832, during which time he was a prominent and colorful figure in Trenton society and a local leader of the Catholic Church. While in Trenton, he also displayed an entrepreneurial streak, which was reflected in his dealings with the Philadelphia shipping merchants Jeremiah and William R. Boone; in his manufacture of pasta (also conducted on the Rosey Hill property); and in his prolonged involvement in the printing of cotton cloth. ${ }^{21}$

Along with Peter A. Hargous, a member of another wealthy local Catholic family of French origin, Sartori formally incorporated his calico printing business in 1820 as "The Trenton Calico Printing Manufactory of Bloomsbury." The company was set up specifically for the purpose of manufacturing and printing wool, cotton, silk, flax and hemp. $^{22}$ As the corporate name implies, however, calico, which in its narrowest and most widely understood sense referred to printed cotton cloth, was the main focus of the business. The source of the cloth being printed at the Bloomsbury works is uncertain, although it seems likely it took in fabric from the various nearby cotton and woolen mills on the Assunpink and Petty's Run. ${ }^{23}$ The Trenton Calico Printing Manufactory continued in operation into the late $1820 \mathrm{~s}$, but apparently was not highly profitable. ${ }^{24}$

One final focus of milling activity in Trenton deserves a brief mention within the context of the city's textile manufacturing aspirations. On the banks of the Delaware River close to the William Trent House, roughly midway between the Sartori property and the mouth of the Assunpink, an important mill complex known mostly as Daniel W. Coxe's Mills or

\footnotetext{
${ }^{20}$ Raum, A History of the City of Trenton, 237.

${ }^{21}$ Hunter Research, Inc., "Archaeological Data Recovery Excavations and Monitoring, New Jersey Route 29, City of Trenton, Mercer County, New Jersey. Volume II: Historic Sites," (report prepared for the New Jersey Department of Transportation and Federal Highway Administration, 2002 [draft]).

${ }^{22}$ Records of the Union Manufacturing Company, New Jersey State Archives, Trenton.

${ }^{23}$ Calico printing, while rare in New Jersey in 1820, had been conducted in the state as early as the 1790s. Print works are reported in Springfield in 1792, Paterson in 1794 and Pompton in 1796, although the technology employed is unclear. The calico printing process used by Sartori and Hargous around 1820 is also unknown. Most likely, it involved the pressing down onto fabric of wooden blocks or flat copper plates, each prepared with a pattern that would be used with coloring substances. Such blocks or plates would have been applied with the help of manually operated machinery. There is no evidence to suggest that more advanced water-powered printing machinery, where cloth was made to pass over engraved copper cylinders, was in use. See Edward H. Knight, Knight's American Mechanical Dictionary (New York: Hurd and Houghton, 1876), I:426-428; Mount, "Early Calico Manufacturing," 27.

${ }^{24}$ In 1829, a court judgment was made against the company in favor of Jonathan L. Shreve and George Potts for \$6,000. At that time, Peter A. Hargous and Stacy A. Paxson were listed as directors, William Potts was serving as President, and Samuel L. Shreve was the Treasurer. Sartori is conspicuous in his absence from the roster of officers, and one wonders if he had divested his interest in the company by this time. The Trenton Calico Printing Manufactory fades into obscurity following the court judgment of 1829 and the firm was perhaps dissolved soon after. The Shreve brothers, Jonathan and Samuel, who had been on opposite sides of the judgment, went on to found a more successful multi-faceted and more fully integrated water-powered textile manufacturing operation in Shreveville, Burlington County in the 1830s. Raum, $A$ History of the City of Trenton, 343; Mount, "Early Calico Manufacturing," 29-30; Hunter Research, Inc., "Archaeological Data Recovery Excavations and Monitoring, New Jersey Route 29."
} 
the Bloomsbury Mills emerged in the second decade of the nineteenth century, drawing its power from a wing dam in the Delaware (Figure 4). The first and primary facility in this complex was a merchant gristmill, which effectively superseded the city's original grain processing site at the South Broad Street crossing of the Assunpink (where the Eagle Factory was built). By 1819, according to an advertisement in the Trenton Federalist, the upper part of the Coxe gristmill was being used for wool carding, a hint perhaps that textile operations were spreading into all available milling spaces in the city. $^{25}$

Clearer evidence that Coxe, a brother of Tench Coxe, had been interested in expanding his milling activities beyond grain processing into manufacturing is provided in a sale advertisement for his entire Trenton estate issued on March $21,1825 .{ }^{26}$ In addition to the gristmill, this sale notice references a second, recently built and adjoining three-story stone mill of roughly similar size that is described as "now ready for the reception of any description of machinery." A contemporary watercolor by Robert Montgomery Bird, produced on July 24, 1826, shows the disposition of these two mills, with the later structure looking well suited for use in textile manufacture. ${ }^{27}$ The ultimate use and fate of this section of Coxe's Mills remain unclear, for within a decade or so this stretch of riverfront became the scene of intensive mill development and redevelopment brought about by a large hydro-engineering project that radically changed much of downtown Trenton.

This project, which provided an important, albeit short-lived, boost to Trenton's textile industry, involved the construction of a seven-mile-long power canal along the left bank of the Delaware River to bring water into the downtown and the Bloomsbury/South Trenton area, and specifically to encourage the development of mill sites for manufacturing purposes (Figure 4). Built by the Trenton Delaware Falls Company in 1831-34, this urban water power spurred the development of nearly 20 mill sites over the following 12 years, although this was considerably fewer than the number originally envisaged. In part because the potential of the power canal was never fully realized, and in part because of indebtedness incurred from the canal's construction and maintenance, the Trenton Delaware Falls Company went bankrupt in the early 1840s. Before the decade was through, the waterway was co-opted by Peter Cooper and the Trenton Iron Company and reconstituted as the Trenton Water Power, continuing in use through the remainder of the nineteenth century and serving a handful of textile mills in addition to the rolling mills of the Trenton Iron Company (later the New Jersey Steel and Iron Company) and various other facilities. ${ }^{28}$

James Hoy's Trenton Cotton Factory was one of the first mills to take advantage of the new power canal, reconfiguring its hydropower system in the mid-1830s to draw water

\footnotetext{
${ }^{25}$ Trenton Federalist, September 13, 1819.

${ }^{26}$ Trenton Federalist, March 27, 1826.

${ }^{27}$ Robert Montgomery Bird, "Trenton Bridge ... From Above ... July 24 1826. R.M.B.” Watercolor held by the University of Pennsylvania.

${ }^{28}$ Hunter Research, Inc., "Archaeological Data Recovery Excavations and Monitoring, New Jersey Route 29."
} 
via a headrace that tapped the canal just below the aqueduct that carried the water power over the Assunpink (Figure 3). Hoy also purchased the land on which the factory was built from Lewis Waln in $1834,{ }^{29}$ a property transfer that was likely connected to the Trenton Cotton Factory's reconfiguration of its hydrosystem (the factory probably ceased using water from the Eagle Factory millpond at this time). In 1837, Hoy's cotton mill was valued at $\$ 75,000$, drew a 250 -square-inch head of water from the power canal and was producing 300,000 yards of cotton goods annually. ${ }^{30}$ The factory possibly suffered a contraction in its business as a result of the Panic of 1837. More certain is the devastating effect of the great flood of early January 1841, which took a heavy toll on many Trenton homes and businesses. A contemporary newspaper account reports that " $\mathrm{t}]$ he dye house and lower story of Mr. Hoy's Cotton Factory were flooded for several days." 31 The factory returned to full production and continued under Hoy ownership until 1852, when it was sold to Samuel K. Wilson, following a fire in the preceding year. ${ }^{32}$ Under Wilson ownership, the mill switched its emphasis to woolen manufacture and operated into the twentieth century. ${ }^{33}$

The power canal of the Trenton Delaware Falls Company supplied the impetus for several other textile mills and related industries in the late 1830s and early 1840s. Just downstream of Hoy's cotton mill, Samuel Croft and Daniel Lodor erected a bone button factory in 1836-37. Around the same time, a branch raceway was constructed to link the main power canal to the Bloomsbury Mills adjacent to the William Trent House. A series of new mills appeared along the branch, among them a textile factory known as the Orleans Mill, which later came under the control of Samuel K. Wilson.

At the downstream end of the power canal below Federal Street, the Union Manufacturing Company built a cotton printing works on the site of the old Trenton Calico Printing Manufactory in 1837, adapting the old calico works so that it could make use of water power (Figure 4). This business was joined in 1842 by the cotton mill of the New England Manufacturing Company of South Trenton, a firm incorporated for the purpose of "manufacturing, bleaching and printing all goods of which cotton or other fibrous materials form a part." Two or three years later yet another cotton mill was erected nearby by Andrew Allinson. The Union print works was destroyed by fire in 1850, while in 1854 the property occupied by the New England cotton factory was acquired by the Trenton Iron Company. By 1856 both mill sites were subsumed within the latter's rapidly expanding rolling mill complex. The Allinson mill, however, shifted into woolen production, becoming known as the Saxony Woolen Mill, and continued in operation into the early twentieth century. ${ }^{34}$

\footnotetext{
${ }^{29}$ Burlington County Deed I3-399.

${ }^{30}$ Joseph C. Potts, The New Jersey Register (Trenton: William D’Hart, 1837).

${ }^{31}$ Emporium and True American, January 15, 1841.

${ }^{32}$ Mercer County Deed W-461; Raum, A History of the City of Trenton, 236.

${ }^{33}$ Hunter Research, Inc., "South Broad Street Bridge," 4-60 to 4-62.

${ }^{34}$ Records of the Union Manufacturing Company; Raum, A History of the City of Trenton, 343, 346, 442443; Hunter Research, Inc., "Archaeological Data Recovery Excavations and Monitoring, New Jersey Route 29."
} 
The one textile manufacturing facility that did not hook up to the Trenton Delaware Falls Company's power canal was the Eagle Factory. Because of its location further upstream along the Assunpink, it was not in a position to draw off water power from the new canal. The Eagle Factory mills were fortunate in having their own millpond and hydropower system, independent of the power canal, although it is unlikely that this enabled them to function any more productively than their competitors. Prior to the construction of the power canal in the early 1830s, the Eagle Factory was indisputably the dominant textile manufacturing concern in Trenton; following completion of the power canal, the Eagle influence waned and the factory was up for sale by the mid-1840s.

\section{The Waln Family Enterprises}

Although the footings laid for the Eagle cotton mill in 1814-15 were likely constructed of local Wissahickon schist, the true foundation of the Eagle Factory was wrought from the personal fortune of Robert Waln (1765-1836) (Figure 5). Robert was the great-grandson of Nicholas Waln (circa 1650-1721), the progenitor of the Waln family in America. Nicholas arrived in Pennsylvania in 1682, crossing the Atlantic aboard the Welcome in the company of William Penn and securing a spot for his family in the upper echelons of Pennsylvania's Quaker aristocracy. Robert Waln's father, also named Robert, was a prosperous Philadelphia merchant and ship owner. He died in 1784, leaving his son both considerable wealth and the difficult task of managing the family's mercantile affairs. ${ }^{35}$

At the time of his death in 1784, the elder Robert Waln was owner of substantial property in Trenton that was centered on the Trenton Mills, formerly one of the largest colonial gristmills in New Jersey, located at the present-day South Broad Street crossing of the Assunpink Creek (Figure 6). This mill seat and surrounding land, the future site of the Eagle Factory, passed to his daughter, Hannah, wife of Gideon Wells. Over the following half-century, Gideon Wells and, more importantly, Hannah's brother, Robert Waln Jr., developed the family's Trenton holdings for manufacturing purposes. Eventually, in the mid-1830s, they ceded total control of these properties and related businesses to Robert Junior's son, Lewis Waln (Figure 7).

From the mid-1780s into the first decade of the nineteenth century, the Trenton Mills continued in operation as a grain processing facility and seem to have been mostly the responsibility of Gideon Wells. ${ }^{36}$ The business evidently did not fare well. By 1803, Gideon Wells was bankrupt, and his life estate was conveyed to two assignees, Archibald McCall and John Dorsey, who granted the rights to his part of the twenty-nine-acre mill tract to his brother-in-law, Robert Waln. In the same year, Hannah Wells also mortgaged her interest in the mill and other premises to her brother. ${ }^{37}$

\footnotetext{
${ }^{35}$ Henry Simpson, ed., The Lives of Eminent Philadelphians, Now Deceased (Philadelphia: William Brotherhead, 1859); J.G. Lee, Philadelphians and the China Trade 1784-1844 (Philadelphia: Philadelphia Museum of Art, 1984), 122.

36 Nottingham Township Tax Ratable Assessments 1803, 1805, 1806, 1807 and 1808.

37 West Jersey Deed AV-151.
} 
Hunter, Sergejeff and Tvaryanas

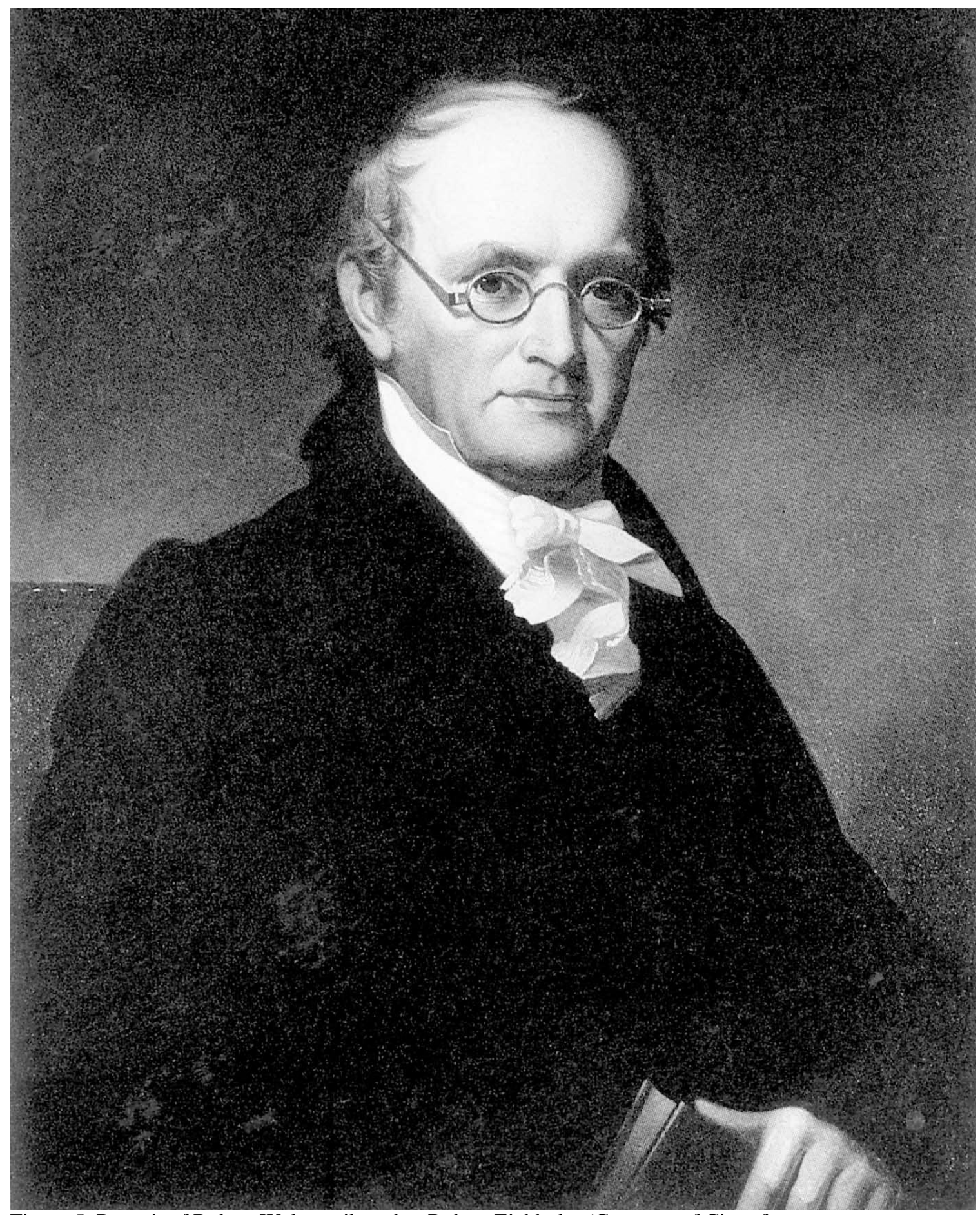

Figure 5. Portrait of Robert Waln attributed to Robert Eichholtz (Courtesy of City of Philadelphia/Fairmount Park). 


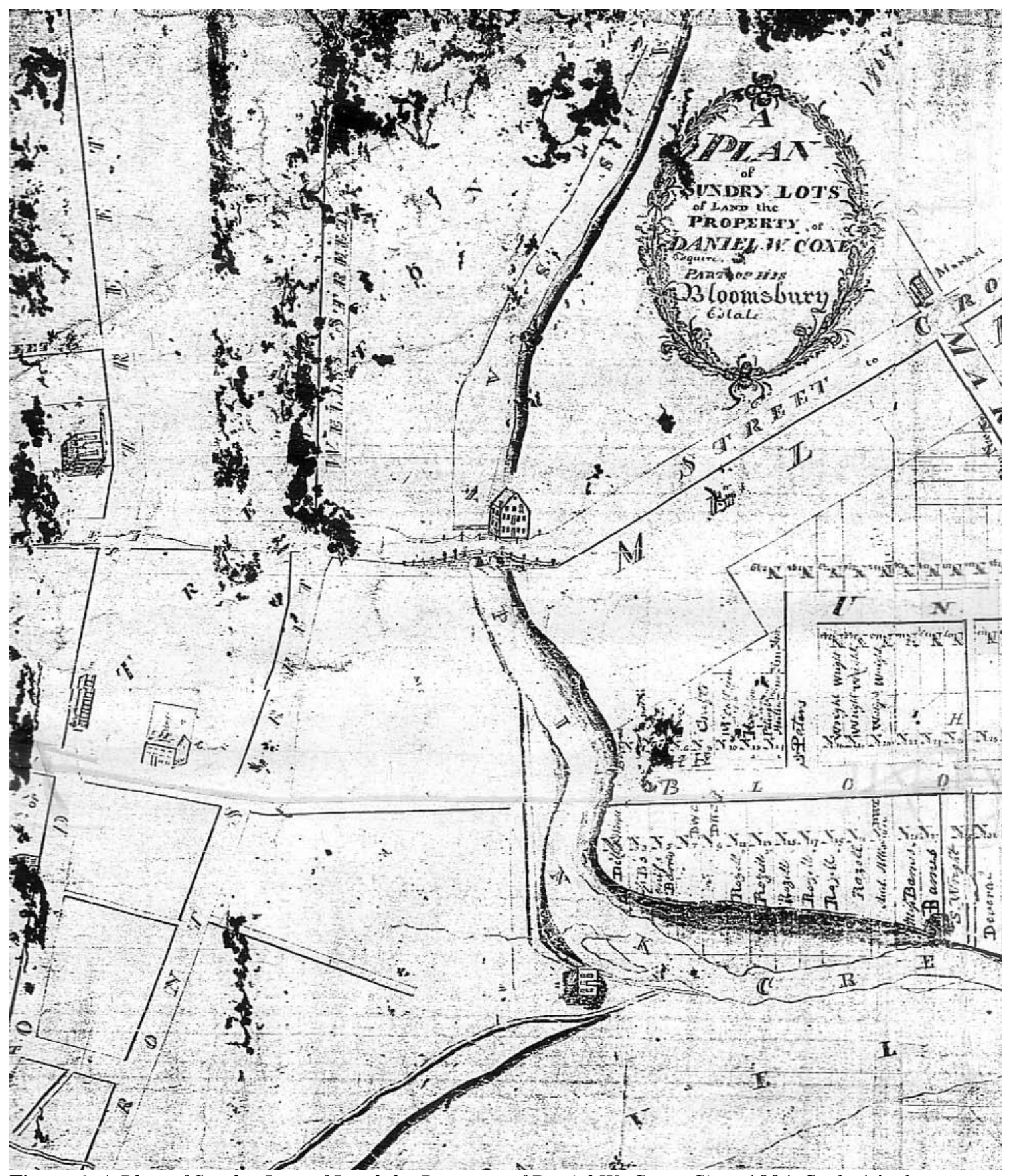

Figure 6. A Plan of Sundry Lots of Land the Property of Daniel W. Coxe. Circa 1804. Scale 1 inch:

260 feet (approximately). Gideon and Hannah Wells' gristmill is shown adjacent to the bridge over the Assunpink Creek.

Several years earlier, following his father's death in 1784, Robert Waln had entered into business with his cousin Jesse Waln and Richard Hartshorne and quickly set about establishing his own reputation in the merchant community. In 1788, Robert Waln, Jesse Waln, Pattison Hartshorne and Ebenezer Large entered into a series of partnerships and formed two separate but closely associated firms, Jesse and Robert Waln and Hartshorne and Large. This arrangement lasted for a decade, but, the partnership of partners was 
terminated in 1798, leaving the firm of Jesse and Robert Waln operating independently as one of the major players on the Philadelphia waterfront. ${ }^{38}$

FIGURE 7.

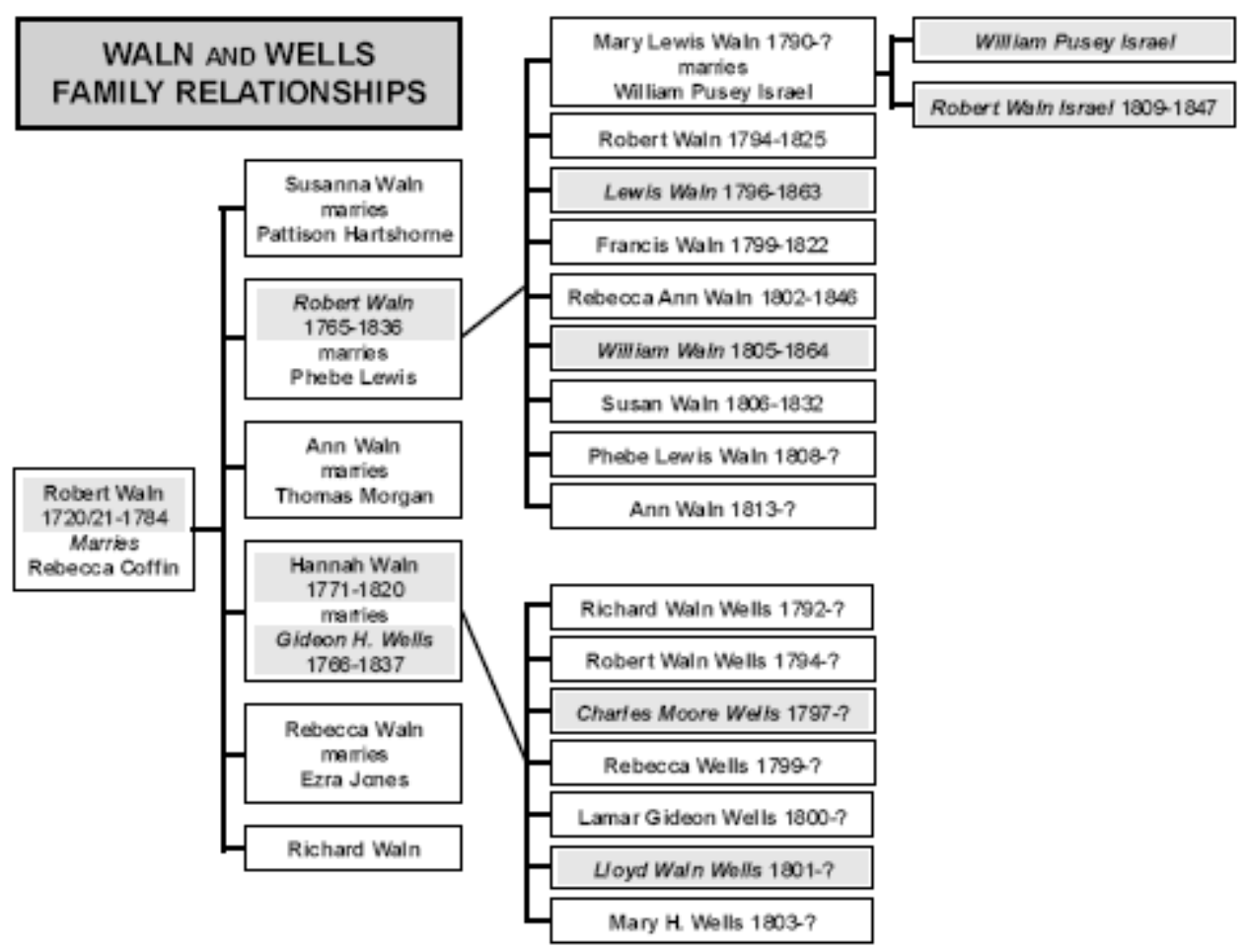

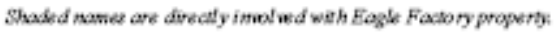

From their counting house at the foot of Spruce Street (Figure 8), Jesse and Robert Waln oversaw a commercial network that extended across the Atlantic to the West Indies, England, and beyond. Initially, most of their activities were focused on trade between Philadelphia, London and the Caribbean. These were the venerable and well-tried routes of earlier merchant generations founded on the triangular trade network of imperial Britain and colonial America. However, as the eighteenth century drew to a close, the merchants of the fledgling United States looked east to the emerging markets of China and the East Indies. Beginning their investment in the Canton trade in 1796, Jesse and Robert Waln were among the first of Philadelphia's large merchant firms to recognize the potential for trade in the Far East. ${ }^{39}$

\footnotetext{
${ }^{38}$ Abraham Ritter, Philadelphia and Her Merchants: As Constituted Fifty and Seventy Years Ago ... (Philadelphia: Abraham Ritter, 1860), 48; Lee, Philadelphians and the China Trade, 122.

${ }^{39}$ Ritter, Philadelphia and Her Merchants, 59; Lee, Philadelphians and the China Trade, 122.
} 
During this period Robert Waln assumed considerable political prominence, serving first in the Pennsylvania legislature (1794-98) and then in the United States House of Representatives (1798-1801). The firm of Jesse and Robert Waln continued in business until 1805, when Jesse Waln withdrew from the company. Perhaps Jesse's decision was based on deteriorating health, for he died within a year of turning over his share of the firm to his cousin. Although Robert stated that his mercantile activities decreased in the wake of Jesse's death, he went on to send more than 45 ships on long trading voyages over the course of the next decade, most bound for the Orient. Nevertheless, the purported reduction in Robert Waln's trading activities after 1806 corresponded with broader trends affecting American involvement in the global economy. European conflicts and increased British interference in American commerce led to a more than 50 percent drop in the combined value of United States imports and exports in the years between 1806 and $1812 .^{40}$

The outbreak of the War of 1812 only exacerbated the international trading problems of Philadelphia's merchants. On December 26, 1812, the British navy was ordered to blockade the Chesapeake and Delaware bays in an attempt to place a stranglehold on American commerce. Although the ultimate effectiveness of the blockade has been debated, by the end of 1813, United States imports and exports had fallen to less than half of their 1811 levels, a staggering blow to the economy, especially considering that U.S. trade already had dropped significantly prior to this date. Yet worse was still to come. In the spring of 1814, the British navy sent ships into the busy waters of New England and thus extended the blockade to virtually the entire Atlantic seaboard. United States import and export figures for 1814 indicate it was by far the worst year for foreign trade that the young nation had ever seen. For Philadelphia merchants, the only other year of comparable devastation was 1793, when yellow fever had closed the port and emptied the city.

Waln's wharf at the foot of Spruce Street fell idle in 1813 as a result of the blockade. Indeed, for the duration of the war, the docks of Philadelphia were lined with empty ships. Other vessels lay at anchor in the river, while even less-fortunate American ships were bottled up in the harbor at Canton, trapped halfway across the world by British patrols. For Robert Waln, all of this meant substantial losses - loss of money tied up in idled ships and empty warehouses, and loss of profit on stagnated capital. Like many American merchants, Waln transferred his capital away from maritime commerce and into domestic manufacturing. It was within this context that he purchased an interest in the Phoenixville Ironworks in 1812 and soon after set about the business of textile manufacture in Trenton. ${ }^{41}$

\footnotetext{
${ }^{40}$ Lee, Philadelphians and the China Trade, 122.

41 Although from a financial standpoint Robert Waln managed to weather the War of 1812, the troubling times nonetheless took their toll. By 1815, he had essentially retired from the leadership of the merchant firm he had overseen for so many years. Day-to-day management of most aspects of his business, including the affairs related to his investments in the Eagle Factory, were turned over to his second son, Lewis Waln. Robert continued on in semi-retirement, enduring another financial downturn in 1819 and serving as a director of the Bank of North America, the Philadelphia Library Company and the Pennsylvania Hospital, and as a trustee of the University of Pennsylvania and the Estate of Stephen Girard.
} 


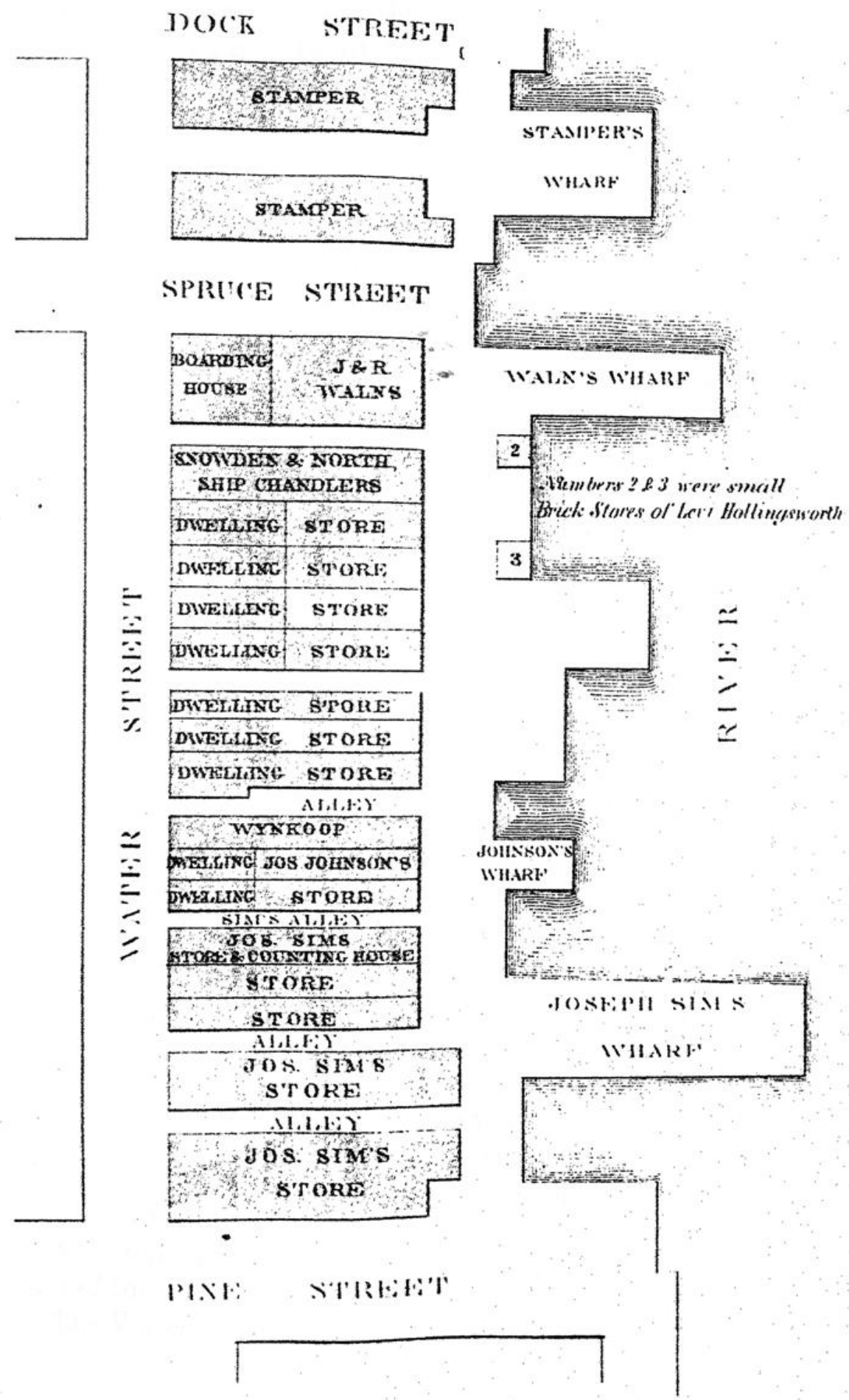

Figure 8. Map of the Philadelphia waterfront showing the location of Waln's wharf (Abraham Ritter, Philadelphia and Her Merchants [Abraham Ritter, Philadelphia, 1860], 49). 


\section{The Eagle Factory: The Robert Waln and Gideon Wells Years (1814-1820)}

By 1814, with their Trenton gristmill still struggling and about to be challenged by a brand new mill erected by Daniel W. Coxe on the banks of the Delaware, Robert Waln and Gideon Wells concluded that the same factors that had made the Assunpink property a choice location for a colonial merchant gristmill might be equally advantageous for a modern textile manufacturing plant. It was this realization that led to the founding of the Eagle Factory. Waln, for his part, agreed to provide the capital for constructing buildings and carrying on the business in exchange for a share in its ownership; the more financially constrained Wells would effectively oversee the operation of the factory. ${ }^{42}$ Waln's motivations in getting involved in the establishment of the Eagle Factory were both altruistic and self-serving. He evidently wished to help out his sister and her husband in a time of financial difficulty and, in a general sense, sought to advance the development of American industry. However, he also wanted to put capital idled by the war back to work and to diversify his commercial interests, thereby making his personal fortune less vulnerable to future disruptions in international trade. Waln and Wells also took the additional step of leasing parts of the mill tract and water power to two other newly founded textile manufacturing enterprises, the Trenton Manufactory of Lawrence Huron \& Company and the Trenton Woolen Manufactory, both to be located immediately downstream of the Eagle Factory. ${ }^{43}$

In setting up the Eagle Factory, Waln and Wells were aware of other, similar ventures. Waln in particular paid heed to other textile manufacturing operations in the Northeastern and Middle Atlantic states and was in contact with mill owners and merchants in New England and Paterson concerning mill machinery and business practices. The Paterson experience was of no small interest, because mills of similar type in reasonable proximity to Trenton were being put into operation around the same time, thus potentially vying for a share of the New York and New Jersey market. ${ }^{44}$

In their initial manufacturing efforts, Waln and Wells, like most other domestic textile merchants, reasoned that if they focused the Eagle Factory's production on coarse fabrics and less refined cotton goods they would be better able to compete with British imports. ${ }^{45}$ By the summer of 1815 , Wells was advertising locally that the factory had for sale "a good assortment of cotton cloth" and was also marketing cotton yarn "warranted equal to any ever manufactured in the United States. ${ }^{.46}$ By early 1817, production had expanded to the point where plaids, checks, bed ticking, shirting, sheeting and stripes were all being sold at the nearby factory store. ${ }^{47}$

\footnotetext{
${ }^{42}$ Robert Waln Account Book, November 26, 1819.

${ }^{43}$ Lewis Waln Letter Book, December 29, 1828, 242, 246 [Gideon Wells]; December 9, 1830, 254 [Garrett D. Wall, Esq.]. All subsequent references to the Waln Letter Book are cited in this format, with Waln's correspondent noted in brackets, preceded by the Letter Book page number. Correspondence cited without any identified correspondent is part of miscellaneous Waln correspondence in the Waln Collection, Historical Society of Pennsylvania.

${ }^{44}$ Mount, "Early Calico Manufacturing," 28.

45 Jeremy, Transatlantic Industrial Revolution, 41, 44.

${ }^{46}$ Trenton Federalist, August 21, 1815.

${ }^{47}$ Trenton Federalist, March 3, 1817.
} 
During the 1810s, however, the price of cotton fluctuated and the market for Trenton textile products proved unstable. In July of 1819, Wells informed Robert Waln that he was prepared to shut down the mill if the company's "tickens," an Eagle Factory bed cloth specialty then selling at "a dreadful price," were no longer accepted by merchants. ${ }^{48}$ Wells put on a braver face for the census taker in the following year, noting that " $[\mathrm{t}] \mathrm{he}$ Establishment is doing pretty well considering the general depression of the Times, and does not appear to require any additional protection from the .... Government." 49

Yet, at around this time, and largely because of the difficulty in sustaining the business, a more serious situation was developing behind the scenes, which soon caused the Robert Waln - Gideon Wells partnership to unravel. Between May and September of 1819, Wells was involved in court proceedings with the Trenton Banking Company concerning his defaulting on a mortgage of $\$ 22,000$ for his share of the mill property. ${ }^{50} \mathrm{Waln}$, from notes in his account book and correspondence in early 1820, appears not to have been aware of this mortgage, and believed he had a prior claim on Wells' Trenton assets, stemming from the financial arrangements made in setting up the Eagle venture. ${ }^{51}$ Finally, in 1819, with the cotton industry still in dire straits, Waln transferred his share of the Eagle Factory and associated property to his trustees. ${ }^{52}$ Waln and Wells then advertised the factory property for public sale in early November of that year (Figure 9), with the clear indication that any transaction would be subject to the conditions governing Wells' life estate. ${ }^{53}$ The sale, slated for December 7, 1821, apparently attracted no buyers. In the following year, Robert Waln's son, Lewis, took over the enterprise, purchasing his father's interest in the Eagle Factory for $\$ 15,000 .^{54}$

Lewis Waln's involvement with the Eagle Factory dates from at least 1820, and, judging from some specific accounting procedures he set up with regard to Gideon Wells's activities, he appears to have been overseeing much of the mill's business from Philadelphia by May of 1821, presumably on behalf of his father. ${ }^{55}$ Thus began the period of Lewis Waln's control over the Eagle Factory, which extended over almost three decades. Making use of Lewis Waln's letter book and correspondence, along with census data, newspaper advertisements and maps, the following sections of this article consider various facets of the Eagle Factory - management and labor; the physical plant; raw materials and products - before summarizing the subsequent history of its operations from the early 1820 s into the early 1840 s.

\section{Management and Labor}

Management of the Eagle Factory was accomplished through a close-knit, three-tiered

48 Gideon Wells to Robert Waln, July 20, 1819.

49 United States Federal Census of Manufactures 1820.

50 New Jersey Superior Court Docket \#42121.

51 Robert Waln Account Book, November 26, 1819; Robert Waln to Benjamin Morgan and John C. Smith, March 10, 1820.

52 Burlington County Deed R2-107.

53 Trenton Federalist, November 12, 1821.

54 Burlington County Deed R2-107.

55 Lewis Waln Letter Book, May 7, 1821, 64 [Gideon Wells]. 
hierarchy of owners, superintendents and overseers, with family ties often playing an important role in determining who filled positions in the two upper tiers (Figure 7). The owners supplied the capital, hired the senior staff, handled the accounts, made decisions about the purchase of machinery, and set company policy with regard to production. The factory superintendent was responsible for making sure that the factory was running efficiently and being operated safely. The superintendent was aided by his subordinate overseers, who supervised the labor force and likely received bonuses when the factory workers exceeded specified production levels.

As noted above, ownership in the early years was shared by Robert Waln and his brotherin-law, Wells. In 1822, Robert Waln's ownership stake was conveyed to his second son, Lewis, who shared tenurial control of the factory property with the Wells family until 1829, at which point he assumed sole ownership of the Eagle Factory site. ${ }^{56}$ The Walns, based in Philadelphia, held the purse strings and effectively had the final say in the factory's management. Wells, living in Trenton (probably in the main dwelling on the original mill tract), functioned both as an owner and as the principal on-site manager of the mill's daily operations up into the mid-1820s; his sons, Charles and Lloyd Wells (Lewis Waln's cousins) succeeded him. ${ }^{57}$

Robert Waln initially sought a superintendent with New England mill experience to assist Wells in the daily management of the factory, but had no success finding a suitable candidate. Eventually, a Mr. Longstroth (probably John Longstreth, a member of a prominent local milling family) took the position. ${ }^{58}$ By 1821 James Hoy appears to have been serving in a senior management position, either as superintendent or overseer, for in July of that year he was entrusted with the task of going to Philadelphia to select cotton for the Eagle Factory. ${ }^{59}$ By January of 1826, however, Hoy had been recently discharged by Lewis Waln, ${ }^{60}$ moving soon after to take on a senior post at the neighboring Trenton Cotton Factory, where he eventually gained full ownership in 1834.

From the mid-1820s onward, in concert with the gradual exit of his uncle, Gideon Wells, Lewis Waln frequently relied on family members to handle the running of the Eagle Factory, entrusting management tasks at various times to his cousins Charles and Lloyd Wells, his brother William, and his nephew William P. Israel. By January of 1826, Gideon's sons, Charles and Lloyd (who later moved to the mill community of Somersworth, New Hampshire) appear to have been supervising the Eagle Factory. ${ }^{61}$ By

\footnotetext{
56 Burlington County Deed L-563. Lewis Waln continued to share ownership of the site of James Hoy's neighboring cotton mill until 1834.

57 The latest communication from Lewis Waln to Gideon Wells in the Lewis Waln letter book occurs on December 28, 1828, by which time it appears that Charles Wells is effectively partnering with Waln. An earlier communication of January 13, 1826 also suggests that Charles and Lloyd Wells had assumed most of Gideon Wells's supervisory responsibilities at the factory.

58 Mount, "Early Calico Manufacturing," 28.

59 Lewis Waln Letter Book, July 20, 1821, 78 [Gideon Wells].

${ }^{60}$ Lewis Waln Letter Book, January 13, 1826, 231 [Gideon Wells].

61 Ibid.
} 
1827, and continuing up until the fall of 1829, Lewis Waln's brother, William, and his cousin, Charles Wells, were managing the establishment. ${ }^{62}$

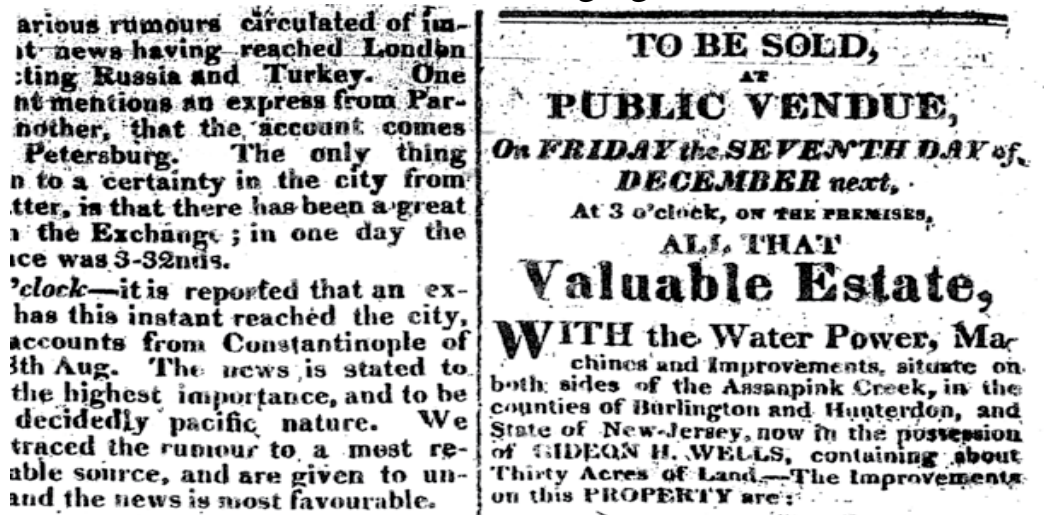
and the mewsis most faveurible.

e departure of his majesty for the tent is no longer a matter of conThe Gazette of last night ins the appointment of the " Iionts ses for the administration of the timent duriz:g his niajesty's ab. e," which is further declaped, nly "be "for a short time." "The s Justices consist of his Royal ness the Duke of York, the Arch$p$ of Canterbury, and the Cabilinisters. His majesty's depar. is expected to take place about tter end of this week.

the sone court if was ordered by rjesty in council, that Parliament d he further prorogued from the Sept. to the I9th November.

mentionted on Montay, that Sir $t$ Uylson had been dismissed from my; and in the siazette of last tihis very smeasure is announced in ollowing terms:- "War Affice 17. Memorandum. 'The king has pleased to remove Sir Robert Wilca his majesty's service." It is, irse asscrted by the Radical press, his measure is in consequence of vitiral sentiments of Sir Robert, veciuse he is always opposed to ters. Sir Robert, himself, or we istaken, knows a better_reason; $\epsilon$ ill venture to add, that whatmortification he mag experience. Is no surpirise at the measure.

etter from Consiantiniople, dated 10th, received in Glasgow this ing. (Monday 17th inst.) saysiirs here are more tranquil than have been these many months. or peace with Russia is still a try ; but I hope that the destruconsequeaces of a contlict between iuch exasperated and formidable 18 will be uvoided, as the Porte ven in. even to the most extravin-

Figure 9. Advertisement for the pub

Federalist, November 12, 1821).

In 1831, Lewis Waln was looking beyond the immediate family for management expertise, intending to hire William Hines of Sandy Hill, New York, as a new

${ }^{62}$ William Waln to Lewis Waln, January 16, 1827; Charles W. Wells to Lewis Waln, September 29, 1829; Waln \& Leaming to Charles W. Wells, September 29, 1829.
Legislature o HOUSE OF

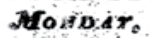
Petitions wert pre Essex för sin Act to $c$
Societies, referrod tc jeck.

Mr. Wiison propas thorize the clerk to Mup of the U: State Legisiature-lail on

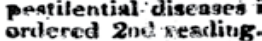
3 e'clock the Hou presented from inh. duction of the rate Easex for encuurag Societies- reak and Mr. Egbert reporte bower part of the co new county, to be Lawr.nce, with an read and orde-ed to The bill to nbolish as read second $t i$ The bill to repeat and that respecting d E-neral postponed.

Mr. Ewing from t? rcferred the bill to the Newark and 'Tre nies, reported the Ineit.

The bill for the sa ty at Paterson :maseed Ghas, Hawlesbergh, enanimously. Adjou TUESAA

Mr. Etlgar presen pary to encourage do vir. vewbold

Me rase of interepo $2 .+$ rearlingerest in act resuecting fences pust pon'd.

Billy fuased-The hi zer of the Newret. C.ra; ranics, 33 k. ? Tluman Redman, jun therein mentioned: cupital stucle of the Britywick the sill fo longing "1" the state to repeat the act for howse is the rity of $\mathrm{T}$ ing the same; and the penses of government, were seint to council.

3 o'cluck the hombe, rates of uniform com Sussex Brigade, to be The bill to alter the read a third time and Mr. Dickerson prese
Ackermsi. ensonitieis Novemiber \$d, 1821. 85. $4 \mathrm{w}$ Mr. Johnsofit repost goveruruchit house, prevented a petition dent-battarion - comn the counties of Cumbe 
superintendent with the specific charge of directing the machine shop and the factory. ${ }^{63}$ Around this time, Waln was also receiving detailed correspondence from his nephew, Robert Israel, who was then in Lowell surveying the mills there. Robert Israel later removed to Portsmouth where he worked for the Great Falls Manufacturing Company and supplied throstles for the Eagle Factory. ${ }^{64}$ In its waning years in the early 1840 s, the Eagle Factory was managed by another of Lewis Waln's nephews, William P. Israel. ${ }^{65}$ In 1845, with the factory up for sale, William Israel left Trenton for Portsmouth, New Hampshire, where he set up a business manufacturing looms. ${ }^{66}$

In many respects, the management structure at the Eagle Factory, with its strong basis in the Waln and Wells families, resembled that of many late-eighteenth- and earlynineteenth-century textile mills in Rhode Island and eastern Massachusetts. In New England mill villages like Slatersville in the Blackstone Valley, the owners/partners engaged in hands-on mill management and knew intimately the milling processes and machines involved. Samuel Slater was notoriously distrustful of outsiders and believed strongly that a successful textile manufacturing business would ensue when actively managed by a partner or son. At Slatersville, when a mill manager retired, Slater typically turned to his family rather than a professional agent to find a replacement, averring that successful manufacturers "employed their families .... and, to the extent of this savings of the wages and superintendence and labor, realized the gross profits of manufacture." ${ }^{\circ 7}$

With regard to the mill labor force, in its early years of operation the Eagle Factory probably again followed the Slater model in which mills frequently employed entire families - husband, wife and children. Under this system, families could express a preference for where their children were employed and sometimes they would all work together. Setting family influence aside, men were assigned the highest-paying jobs (as overseers, managers, spinners, watchmen, second hands) and age was often a factor in addition to gender. Overseers were often males in their thirties or forties, while second hands were usually in their twenties. Women typically operated the power looms. Boys and girls, sometimes as young as seven and working for minimal pay, performed many of the more menial tasks that adults avoided, such as picking cotton. ${ }^{68}$

The earliest labor data for the Eagle Factory are given in the federal manufacturing census of 1820, in which Gideon Wells reported employing 120 men, 60 women and 250

63 Lewis Waln Letter Book, August 16, 1831, 259 [W. Hines]; August 30, 1831, 260 [W. Hines]; October 11, 1831, 262 [W. Hines].

${ }^{64}$ Robert W. Israel to Lewis Waln, August 9, September 30 and November 12, 1831, Waln Collection, Historical Society of Pennsylvania.

${ }^{65}$ William P. Israel to Lewis Waln, March 29, April 6, July 8, July 13, July 18 and August 17, 1843, Waln Collection, Historical Society of Pennsylvania.

${ }^{66}$ William P. Israel to Lewis Waln, July 28, 1845, Waln Collection, Historical Society of Pennsylvania. This letter indicates that Israel's initial loom design was not "taken well in Boston," but he persisted and reported receiving a request for up to four hundred looms, some of which were destined for Cohoes, New York.

${ }^{67}$ Barbara M. Tucker, Samuel Slater and the Origins of the American Textile Industry, 1790-1860 (Ithaca, New York: Cornell University Press, 1984), 103.

${ }^{68}$ Tucker, Samuel Slater, 104. 
children for a total annual wage of $\$ 26,000 .{ }^{69}$ There is no easy way of assessing the degree of family representation or establishing a full breakdown by gender, although the fact that women and children accounted for 72 percent of the factory's labor pool was not unusual for the time, when the nation's industrial workforce as a whole displayed a similar ratio. ${ }^{70}$ In 1833, Lewis Waln reported that the Eagle Factory employed 40 men, 80 boys and an unspecified number of girls, although one suspects the latter figure would have been well in excess of $100 .^{71}$ Waln's reliance on women and children for labor, which bordered on the exploitative, is made plain in a communication to Patrick Jackson, Chairman of the Committee on Cotton, in which he comments that in the United States "the wages of labor are received principally by women $\&$ children, whose labor under the circumstances would be of little value so that nearly the whole amo't of their wages might be considered as gained in an estimate of the National industry." "72 The Eagle Factory likely employed very few immigrants, since this practice was not widely adopted until the middle of the nineteenth century.

Judging from his correspondence in the 1820s, Lewis Waln did not anticipate difficulty in finding workers for the Eagle Factory. In early 1823, having reduced his weavers' wages due to a decline in the price of hand loom goods, he noted that "altho' no doubt disagreeable to the weavers [this] ought not to occasion such dissatisfaction as there are hundreds here who would be glad to be in their situation." ${ }^{, 73}$ By 1825 , however, the female component of the factory workforce was evidently in need of bolstering, as indicated by contemporary newspaper advertisements searching for 16- to 20-year-old girls (Figure 10). This development may reflect both the laying off of hand loom weavers and the factory's increasing reliance on power looms, two related trends evident at the mills during the mid-1820s. ${ }^{74}$ It perhaps also hints that the Eagle Factory was consciously adopting facets of the Waltham-Lowell system, shifting away from traditional family labor and looking to hire girls and young single women from surrounding agricultural areas. The fact that the Eagle Factory was situated within an existing population center may have further affected the composition of the labor force, causing fewer entire families to be hired. It is not known how and where the millworkers were housed, although the early-nineteenth-century development of the residential neighborhood known as Mill Hill may have been spurred in part by the textile mills on the Assunpink.

\footnotetext{
${ }^{69}$ United States Federal Census of Manufactures 1820.

${ }^{70}$ Tucker, Samuel Slater, 145.

${ }^{71}$ McLane, Documents Relative to the Manufactures in the United States, 168-169.

${ }^{72}$ Lewis Waln Letter Book, January 5, 1832, 265-268 [Patrick Jackson].

${ }^{73}$ Lewis Waln Letter Book, January 9, 1823, 142 [Gideon Wells].

${ }^{74}$ Lewis Waln Letter Book, May 28, 1824, 210 [Gideon Wells]; July 19, 1825, 225 [Gideon Wells].
} 


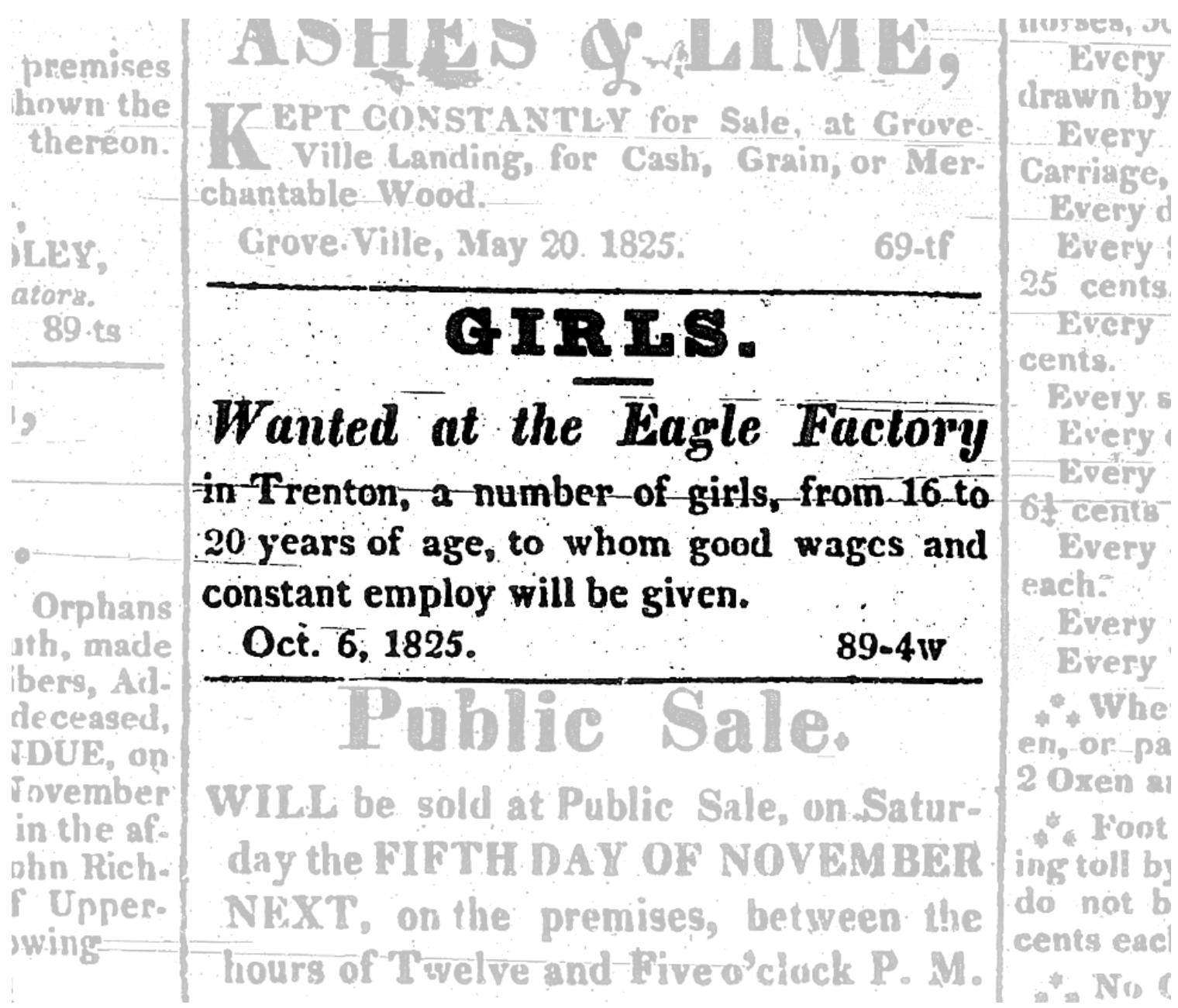

Figure 10. Advertisement seeking girls for employment at the Eagle Factory (Trenton Federalist, October $31,1825)$.

\section{Physical Plant}

At the peak of its development in the 1820s and 1830s, the Eagle Factory comprised at least three separate water-powered industrial buildings, an elaborate hydropower system, a dye house, a sizing house, a drying house, a blacksmith shop and several other smaller ancillary buildings, including a pair of storehouses, an office and the Eagle store, where factory goods were available for sale. The entire complex occupied almost 30 acres and extended across both sides of the Assunpink Creek, upstream and downstream of the Greene Street (present-day South Broad Street) bridge (Figure 11).

The dominant feature of the factory was the large mill building erected in 1814-15 on the south bank of the creek immediately downstream of the Greene Street bridge. Only a single image of this building has been found (Figure 2) and its footprint appears on only a handful of mid-nineteenth-century maps, but its basic dimensions and essential form are described in several newspaper advertisements and inventories prepared for insurance 
purposes. $^{75}$ In 1824, Lewis Waln, in furnishing information to Ralston \& Lyman, prospective insurers, reported that " $[\mathrm{t}]$ he factory is of brick, 5 stories high, exclusive of the basement, which is underground, length 54 feet, breadth about 38 feet." He went on to note that the structure was "substantially built and plastered .... the stairs are carried up in a brick building adjoining which has a cupola and bell .... [and] the waterwheel is on the outside of the factory enclosed partly with brick and partly frame."76 The descriptions provided for insurance purposes contain numerous other details about the building, many of which focus on its heating system and fire precautions. Waln was acutely aware of the risk of fire from malfunctioning machinery and the various manufacturing processes being conducted in the building.

Each floor of the Eagle Factory (as the building was usually known) was given over to a specific manufacturing activity. The first and second stories were used for spinning, the third and fourth for carding, while the fifth housed mules (spinning machines) for producing the finer and softer yarns used as weft on the loom. The data provided to Ralston \& Lyman in 1824 included details of the machinery on each floor: 10 throstles (with a total of 960 spindles), two spooling machines and one bobbing machine on the first floor; 10 throstles (864 spindles) on the second floor; 26 carding machines, four roping frames and four drawing frames on each of the third and fourth floors; and three mules (679 spindles) on the fifth floor. ${ }^{77}$ This arrangement and quantity of machinery appears to change very little between 1820 and 1830. The number of spindles reported in the federal census of manufactures in 1820 was 2,500 , while, in 1829, in information supplied to the Pennsylvania Fire Insurance Company, the machinery is almost identically reported except that an additional mule (with 269 spindles) had been installed on the fifth floor. ${ }^{78}$

It seems likely that from the outset the main Eagle Factory building was used primarily for carding and spinning, and probably continued in this vein into the early 1840 s. There is good reason to suppose that much of the carding and spinning machinery was acquired from New England. As early as October 1815, the firm of Hines, Arnold \& Co. of Rhode Island was advertising in the Trenton newspapers that "cotton machinery built of the best of materials, warranted to operate as well as any now in operation" could be found at the "Eagle Cotton Manufactory" and was presumably available for purchase there. ${ }^{79}$

An important process that preceded the carding and spinning of cotton was the picking and cleaning of the fiber, whereby extraneous matter, such as insects, seeds and dirt, was removed. At the Eagle Factory, this task, probably accomplished by running the fiber through water-powered machines with rotating teeth, was carried on in the old gristmill building on the east side of Greene Street (visible in the foreground of Figure 2).

\footnotetext{
${ }^{75}$ Trenton Federalist, November 12, 1821; Lewis Waln Letter Book, January 9, 1823, 188-189 [Manhattan Fire Insurance Company], May 20, 26, and 28, 1824, [Ralston \& Lyman], June 11, 1829, 246 [Pennsylvania Fire Insurance Company].

${ }^{76}$ Lewis Waln Letter Book, May 20, 1824, 206-207 [Ralston \& Lyman].

${ }^{77}$ Lewis Waln Letter Book, May 20 and 26, 1824, 206-208 [Ralston \& Lyman].

${ }^{78}$ United States Federal Census of Manufactures 1820; Lewis Waln Letter Book, June 11, 1829, 246 [Pennsylvania Fire Insurance Company].

${ }^{79}$ Trenton Federalist, October 28, 1815.
} 


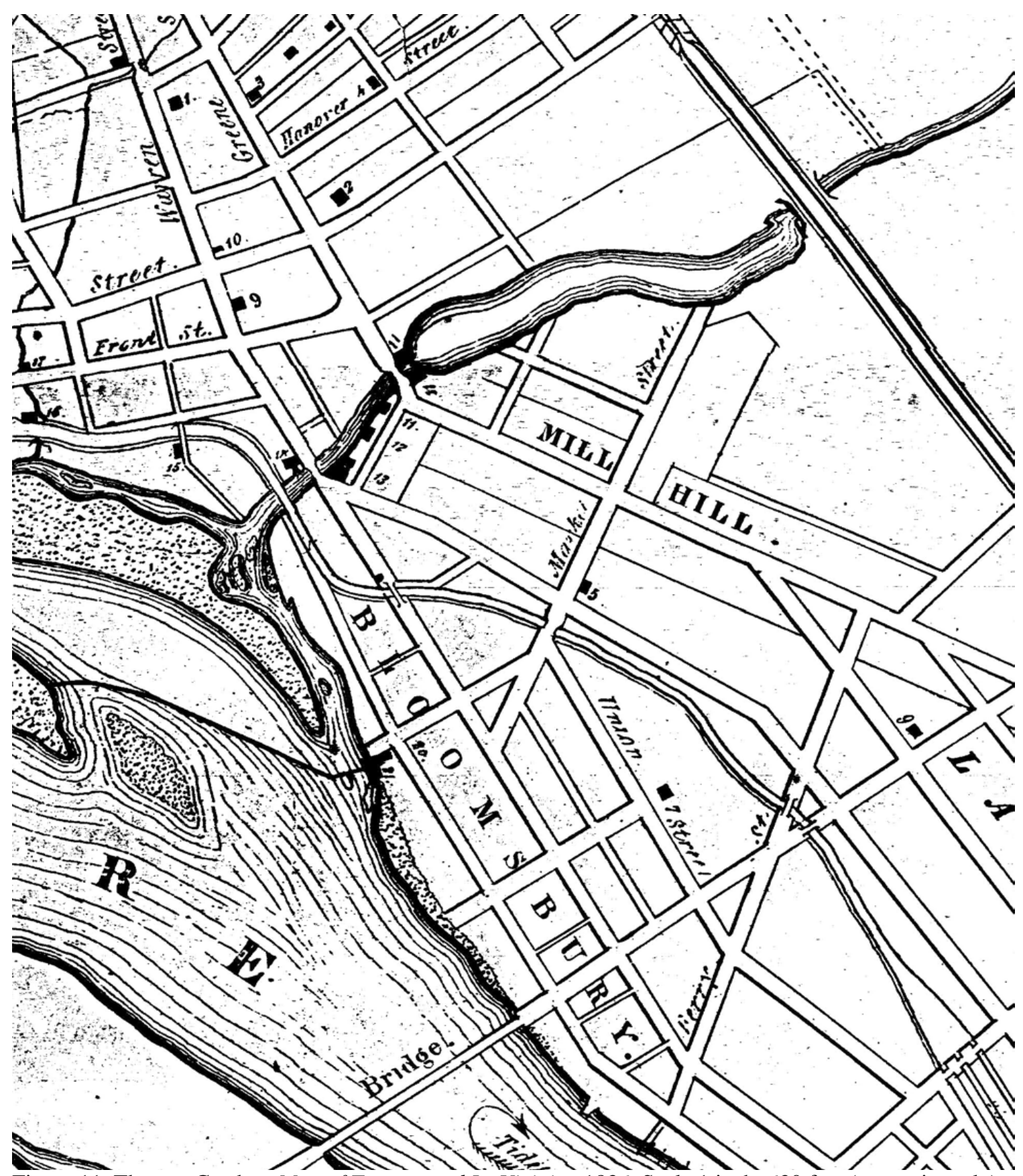

Figure 11. Thomas Gordon. Map of Trenton and Its Vicinity. 1836. Scale 1 inch: 630 feet (approximately). The three buildings annotated as " 11 " were part of the Eagle Factory complex, "12" was James Hoy's Trenton Cotton Factory.

Lewis Waln was always at great pains to emphasize to potential insurers of the factory that this work was conducted in an entirely separate building, since the machinery was a potential fire hazard. ${ }^{80}$ The old stone gristmill was also used for dressing the cotton fiber, which entailed its immersion in vats, and part of the building also served as a machine

${ }^{80}$ Lewis Waln Letter Book, November 6, 1822, 135 [Providence Insurance Company], May 20, 1824, 208 [Ralston \& Lyman]. 
shop for the mills in the 1820s. Toward the end of the factory's life in the 1840s, parts of the gristmill building were separately rented out to non-textile-related businesses. ${ }^{81}$

A third water-powered industrial building within the Eagle Factory complex was the weaving mill, also referred to as the power loom building, situated on the north bank of the Assunpink on the east side of Greene Street. This structure was probably not erected as part of the original construction in 1814-15, since no clear reference to the presence of power looms at the factory has been found prior to 1821. The development of power loom machinery in the United States was still in its infancy in 1814 and it is reasonable to assume that the only machinery on the Eagle site at the outset was involved in the picking, cleaning, carding, spinning and warping processes. Weaving in these earlier years was likely undertaken by a group of women and girls, and perhaps a few men, using hand looms. Some of this equipment stood on the mill premises (in unused space in the main factory building and the old gristmill), but much of it was probably distributed around the Trenton area in local homes.

The Eagle Factory's transition from hand to power loom weaving appears to have occurred progressively over the course of the 1820s. The first unequivocal indication of power looms being used at the site occurs in late 1821. The sale advertisement prepared in November of that year by Robert Waln and Gideon Wells notes "a stone factory, containing 30 power looms, with the necessary machinery for weaving cotton goods" (Figure 9), while in the following month, Lewis Waln reports obtaining insurance coverage of $\$ 5,000$ on "the building and machinery in the Weaving Establishment." 82 No mention of power looms is made in either the federal census of manufactures in 1820, nor in an inventory of mill machinery owned by Gideon Wells, compiled in September of 1819 in connection with court actions taken against him over his defaulting on mortgage payments for his share of the Eagle property. ${ }^{83}$ However, it may be relevant that Hannah Wells (Gideon's wife, who retained ownership of the land east and upstream of the Greene Street bridge) purchased water rights to raise the level of the water in the millpond in April of $1819 .{ }^{84}$ This possibly implies an upcoming modification of the Eagle Factory hydropower system to allow for construction of a weaving mill on the north bank of the Assunpink on the east side of Greene Street. Subsequent documents and historic maps make clear that this mill was indeed located on the north bank of the creek across from the old stone gristmill. ${ }^{85}$

Throughout the early 1820s, Lewis Waln's correspondence makes occasional references to the high labor cost and unprofitability of hand loom weaving, while also noting that he

\footnotetext{
${ }^{81}$ Lewis Waln Letter Book, April 5 and 29, 1842, 355-356 [P. Dickinson].

82 Lewis Waln Letter Book, December 15, 1821, 97 [Gideon Wells].

${ }^{83}$ United States Federal Census of Manufactures 1820; New Jersey Superior Court Docket \#42121.

${ }^{84}$ Burlington County Deed Y2-441.

${ }^{85}$ Information supplied by Lewis Waln to Ralston \& Lyman (Lewis Waln Letter Book, May 26, 1824, 208), states that the "power loom building is of stone with the exception of the gable ends which are of wood or frame, it is three stories high about 60 feet front on Greene Street in Trenton and 22 feet deep. Stands directly on the Assanpink on the northerly side ... The power loom building with water wheel running gears including drums and shafts is valued at $\$ 3,500 \ldots 30$ looms with apparatus @ \$30 each.”
} 
was pursuing the purchase of additional weaving machinery. ${ }^{86}$ In July of 1825 , Waln discussed various ongoing cost-cutting measures at the factory, along with a reference that "the hand looms hav[e] been stopped." 87 By January of 1827, based on a report by William Waln to his brother Lewis, there appear to have been two separate weaving facilities: the "old shop" (probably the mill described above), which contained 30 power looms and seven additional Jenks looms; and the "new shop," with 33 power looms. The location of the new weaving shop is uncertain, but descriptions of flood damage in 1843 imply that it lay on the west side of Greene Street, on the south bank of the Assunpink, between the five-story brick factory and the converted gristmill (Figure 2). ${ }^{88}$ William Waln also notes that 34 handlooms were still in use for weaving cottonade and $3 / 4$ muslin, demonstrating that the traditional weaving craft still had a place, albeit somewhat reduced, in the factory system. ${ }^{89}$

The water power source for the three main industrial buildings - the five-story, brick spinning and carding mill; the converted stone gristmill used for picking and cleaning cotton; and the "old" weaving mill erected around 1820 - was a large millpond retained by a dam across the Assunpink Creek roughly 50 to 100 feet upstream of the Greene Street bridge. The oldest of these buildings, the converted gristmill (Figures 2 and 6), dated from at least the mid-eighteenth century and occupied the site of Mahlon Stacy's gristmill, erected in 1679. The five-story brick factory, just downstream, was fed by a raceway that passed along the south side of the converted gristmill, under Greene Street, and then emptied water on to what was probably a breast wheel at the eastern end of the building. This same raceway evidently supplied water power to at least one other mill immediately downstream of the brick factory (the Trenton Manufactory, and perhaps also the Woollen Manufactory of Trenton). In the years before the Trenton Delaware Falls Company's power canal was built, it may also have fed the "new" weaving mill, which is thought to have stood between the brick factory and the gristmill. The "old" weaving mill, on the north bank of the Assunpink, lay directly across the creek from the gristmill, and was powered by a short headrace that drew water form the millpond at the northern end of the milldam.

The Lower Assunpink was beset by several serious floods in the eighteenth and nineteenth centuries, a circumstance that was likely exacerbated by the reconfiguration of the creek for water power usage. Most of the mills, and the Greene Street bridge in particular, suffered damage at one time or another, and the facilities of the Eagle Factory were no exception. The converted gristmill was partially destroyed by a flood in February of 1822, which carried away machinery and equipment used in the picking and dressing of cotton. ${ }^{90}$ This flood may also have damaged the "old" weaving mill; in a letter to Robert Waln in October of that year, Gideon Wells noted that "we have been two weeks putting in a new water wheel in the power loom factory." 91

\footnotetext{
${ }^{86}$ Lewis Waln Letter Book, March 28, 1823, 156 [Gideon Wells], May 28, 1824, 210 [Gideon Wells].

${ }^{87}$ Lewis Waln Letter Book, July 19, 1825, 225 [Gideon Wells].

${ }^{88}$ State Gazette, March 30, 1843; William P. Israel to Lewis Waln, March 29, 1843, Waln Collection, Historical Society of Pennsylvania.

${ }^{89}$ William Waln to Lewis Waln, January 16, 1827, Waln Collection, Historical Society of Pennsylvania.

${ }^{90}$ True American, February 23, 1822; The Emporium, February 23, 1822.

${ }^{91}$ Gideon Wells to Robert Waln, October 31, 1822, Waln Collection, Historical Society of Pennsylvania.
} 
Another spring freshet in March of 1843 caused equally severe or worse damage. Floodwaters blew out the dam and "an old trunk, unused for years, running from the creek on the east side of the stone factory" (possibly the original raceway to the brick factory [apparently replaced by this time]), carried off "the greater part of the weaving mill on the land side" (apparently the "new" weaving mill), and undermined the Eagle store. The southeastern part of the "stone mill" (the converted gristmill) also collapsed. ${ }^{92}$ Repairs followed - the dam was fixed and the raceway was rebuilt - but in the midst of a drought in the following July the waterwheel shaft in the main factory building broke, apparently due to poor maintenance and old age. It was another month before the wheel was replaced and the factory was fully operational again. ${ }^{93}$

\section{Raw Materials and Products}

The Eagle Factory appears to have processed between 100,000 and 200,000 pounds of cotton annually, although there is very little consistent quantitative information on the volume of raw material being consumed. In the 1820 federal census of manufactures, Gideon Wells reported that the factory took in 120,000 pounds of cotton valued at $\$ 24,000 .^{94}$ Similar data compiled by the Secretary of the Treasury in 1833 showed the Eagle Factory annually processing some 170,000 pounds of cotton valued at only $\$ 18,700$, a clear indication of the declining cost of the raw material. ${ }^{95}$

The archival record is similarly reticent concerning the source of the cotton used at the Eagle Factory. In the early years of its operation, with the Waln family actively engaged in merchant activity with the Far East; a portion of the cotton fiber processed in Trenton seems to have been imported from China and the Bengal area of northeast India. ${ }^{96}$ However, as cotton growing expanded in the Southern states and domestic manufacturing responded to protective tariffs on imported goods, the primary source of Eagle Factory cotton soon became the planters of the Carolinas, Georgia, Louisiana and the Tennessee Valley. ${ }^{97}$ Lewis Waln, in his business correspondence, periodically refers to shipments of cotton bales arriving at his wharves in Philadelphia, sometimes noting it as deriving from Louisiana, Carolina or Upland (the more elevated interior regions of the South). ${ }^{98}$ Upon the cotton's arrival, Waln would notify agents of the Eagle Factory to come and select fiber for processing at their mills. ${ }^{99}$

\footnotetext{
92 State Gazette, March 30, 1843; William P. Israel to Lewis Waln, March 29, 1843, Waln Collection, Historical Society of Pennsylvania.

${ }^{93}$ William P. Israel to Lewis Waln, April 6, July 8, July 13, July 18, and August 17, 1843, Waln Collection, Historical Society of Pennsylvania.

${ }^{94}$ United States Federal Census of Manufactures 1820.

${ }^{95}$ McLane, Documents Relative to the Manufactures in the United States, 168-169.

${ }^{96}$ Robert Waln, Jr., to Robert Waln, October 6, 1819, Waln Collection, Historical Society of Pennsylvania; Lewis Waln Letter Book, April 30, 1824, 201 [Gideon Wells].

${ }^{97}$ Lewis Waln Letter Book, January 5, 1832, 265-268 [Patrick Jackson, Esq., Chairman of Committee on Cotton].

${ }^{98}$ Lewis Waln Letter Book, May 6, 1820, 3 [Gideon Wells], May 8, 1820, 4 [Gideon Wells], June 21, 1820, 13 [Gideon Wells], July 18, 1820, 18 [Gideon Wells].

${ }^{99}$ Lewis Waln Letter Book, July 20, 1821, 78 [Gideon Wells].
} 
Over the years, a wide range of cotton goods was manufactured at the Eagle Factory, although, as with the raw materials being used, it is difficult to quantify the production. In 1820, Wells informed the census enumerators that "the quantities of Cotton Cloth manufactured during the year will not fall short of 480,000 yards." ${ }^{100}$ This was almost certainly an overly optimistic projection, as Lewis Waln reported in 1833 the annual production at 100,000 yards from 40 percent more raw material. ${ }^{101}$

During the first decade or so of operation, the production emphasis appears to have been on yarns and hand-woven goods, but from around 1820 onward, machine-made fabrics increasingly dominated. Coarse cotton cloth for sale in the domestic market was the principal output and this was fashioned into a variety of fabrics in different widths and weaves. Among the more common types of cloth made at the Eagle Factory were plaids, checks, muslin, gingham, ticking or bed ticking, sheeting, shirting, chambray, twill, linsey and some distinctive products such as "Wilmington stripes," "Assunpink ticks" and certain types of shawls (Figure 12). ${ }^{102}$ Ensuring the integrity of Eagle products in the marketplace was of some concern, and in 1820 Lewis Waln engaged a Mr. Thomas to design a label with "the words 'Eagle Factory' printed with a French type which he thinks will be less liable to be counterfeited than handwriting." "103 The Eagle Factory has also been suggested as a possible source of the so-called "Trenton tape," a characteristic binding found on many early-nineteenth-century quilts made in the Delaware Valley. ${ }^{104}$

An especially revealing glimpse of the Eagle Factory production is provided in a letter of January 16, 1827, in which William Waln reports back to his elder brother, Lewis, on the mills' output. At that time, 25 of the 37 power looms in the old weaving mill were turning out "jacks" or jaconet, a thin cotton fabric between cambric and muslin, used for dresses and neck-cloths, at the rate of 26.5 yards per loom per day. Nine of the remaining 12 looms were making ticking (cloth used for covering beds), while the final three were given over to flannel, muslin and drilling, all of these producing at the rate of between 13 and 18 yards per loom per day. In the new weaving mill, all 33 power looms were making ticking at a rate of no more than 15 yards per loom per day. Twenty-four of the 34 handlooms still in use at the factory were producing cottonade, a thick, stout cotton fabric; the remaining 10 were making $3 / 4$ muslin. During the winter of $1826-27$, clearly the factory was focused on producing jaconet, ticking and cottonade. ${ }^{105}$

Eagle Factory products were marketed extensively in the Delaware Valley and Middle Atlantic region, but also saw some distribution further afield, not only in the United States, but also overseas. At the site itself, the Eagle store, conveniently located on Greene Street between the mills and the True American Inn, served as a valuable outlet.

\footnotetext{
${ }^{100}$ United States Federal Census of Manufactures 1820.

${ }^{101}$ McLane, Documents Relative to the Manufactures in the United States, 168-169.

102 Trenton Federalist, August 21, 1815; Trenton Federalist, March 3, 1817; Lewis Waln Letter Book, May 7, 1821, 64; April 16, 1822, 122; June 5, 1822, 122; June 17, 1822, 124; September 27, 1822, 134; March 11, 1824, 196 [Gideon Wells].

${ }^{103}$ Lewis Waln Letter Book, October 20, 1820, 34 [Gideon Wells].

${ }^{104}$ Mount, "Early Calico Manufacturing," 61-62.

${ }^{105}$ William Waln, January 16, 1827, Waln Collection, Historical Society of Pennsylvania.
} 
Numerous advertisements appeared in the Trenton newspapers during the 1810s and 1820s offering cotton goods for sale at the factory store. No less important were the Waln \& Leaming store and other commission houses in Philadelphia, where Eagle goods were periodically sold or auctioned. During the depression years of the late 1830s and early 1840 s, in an effort to facilitate trade, the factory issued scrip notes to valued customers as an alternative to hard currency (Figure 13). This mode of exchange was likely acceptable at the Eagle store in Trenton, and perhaps also at Waln \& Leaming's in Philadelphia.

The Waln family's connections with merchants and cotton planters in the Southern states also appear to have led to some distribution of Eagle factory products in these more distant parts. Lewis Waln noted in 1822 that "in a conversation with some Alabama merchants this morning, they said that a stout coarse cotton article for their slaves was very much wanted, something 4/4 wide and of the stoutness of the Linseys made in Trenton .... No. 4 or 5 closely woven I suppose would suit." ${ }^{\text {,106 }}$ While the South may have been a logical outlet for Eagle Factory goods, there is no evidence in Lewis Waln's letter book that markets were sought further north in New England, or even in New York; presumably the mills of Lowell and other textile centers adequately catered to the clothing needs of this region. Domestic sales fluctuated tremendously, however, as the price of coarse cottons fell and tariffs only partially protected manufacturers. To help offset this uncertainty and keep stocks of unsold cloth at a minimum, the Walns developed an important overseas market for Eagle Factory goods in South America. ${ }^{107}$

\section{The Lewis Waln Years (1820-1849)}

Judging from the evidence of his letter book, the Eagle Factory seems to have been in a state of continual change under Lewis Waln's oversight from the early 1820s into the mid-1840s. The types of products and output were frequently adjusted in response to the exigencies of the markets; the technology of the mills and manufacturing machinery was forever under review; and there was a persistent debate, especially in the 1820s, over the profitability of handwoven goods and whether or not to lay off the handloom weavers. The volume of surplus manufactured stock, both in Philadelphia and Trenton, was also a particular concern of Waln's, expressed frequently in his letters to the factory. Perhaps not surprisingly, there are far more references to difficult times than there are to periods of profit.

The spring months of 1822 and 1824 appear to have been times of intense productivity and reasonable profitability, but during the fall and winter of 1820-21 and 1822-23 a declining cotton market took a toll on the factory. In 1826, Waln augmented the premium on the Eagle Factory insurance policy in order to operate the mills during the evenings for a term of eight months - an indication presumably that business was strong.

\footnotetext{
${ }^{106}$ Lewis Waln Letter Book, June 17, 1822, 124 [Gideon Wells].

${ }^{107}$ Lewis Waln Letter Book, December 6, 1822, 139, May 1, 1824, 203 [Gideon Wells].
} 


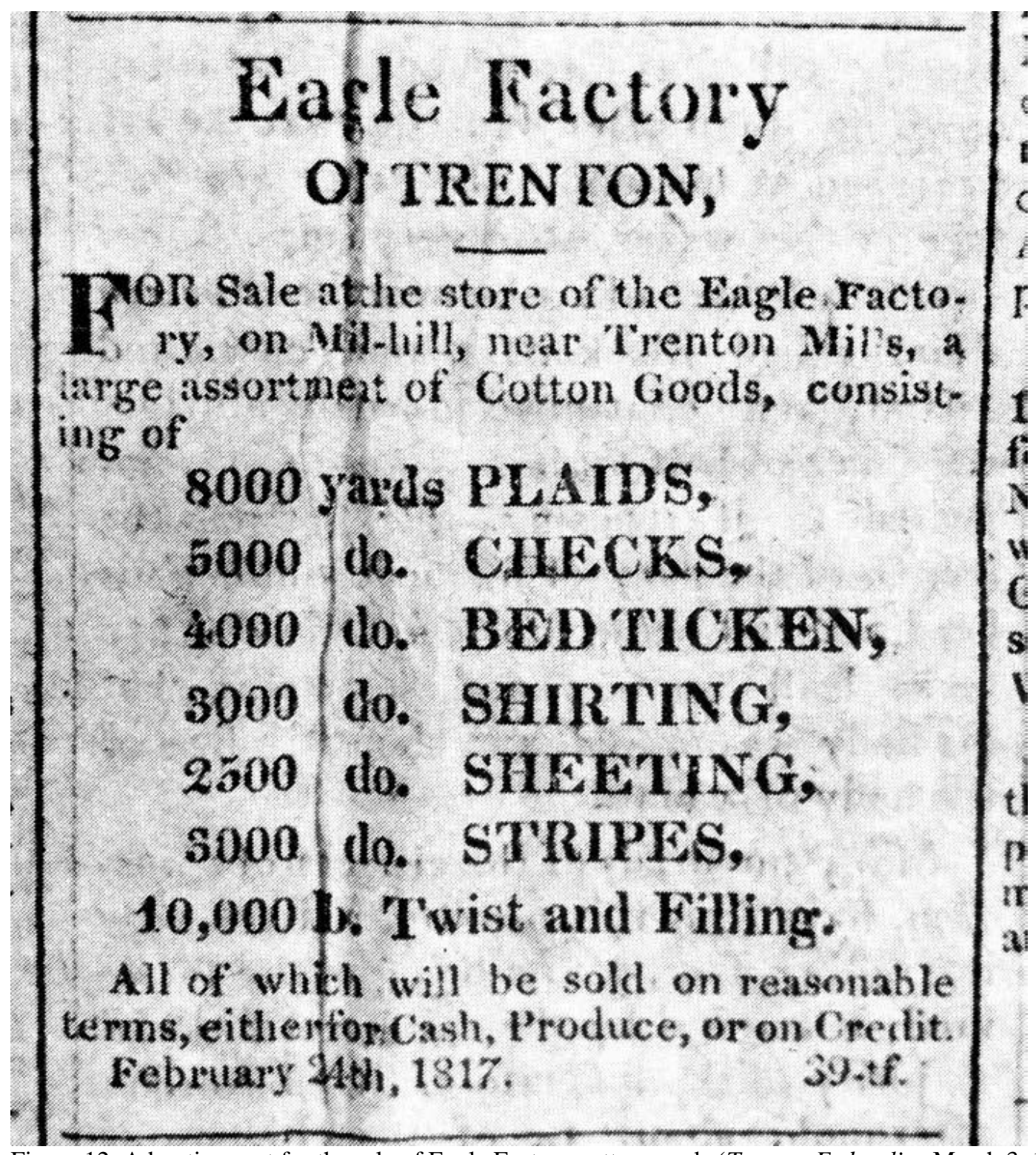

Figure 12. Advertisement for the sale of Eagle Factory cotton goods (Trenton Federalist, March 3, 1817).

Eagle Factory business suffered particularly in 1829, a year in which the price of coarse cottons dipped to a historic low of $81 / 2$ cents per yard. Although not made explicit in the archival record, it seems that the weak market led to a shortage of cash and a breakdown in the supply of cotton goods from the mills in Trenton, which in turn apparently led to a crisis of confidence in Charles Wells' ability to manage the factory. 

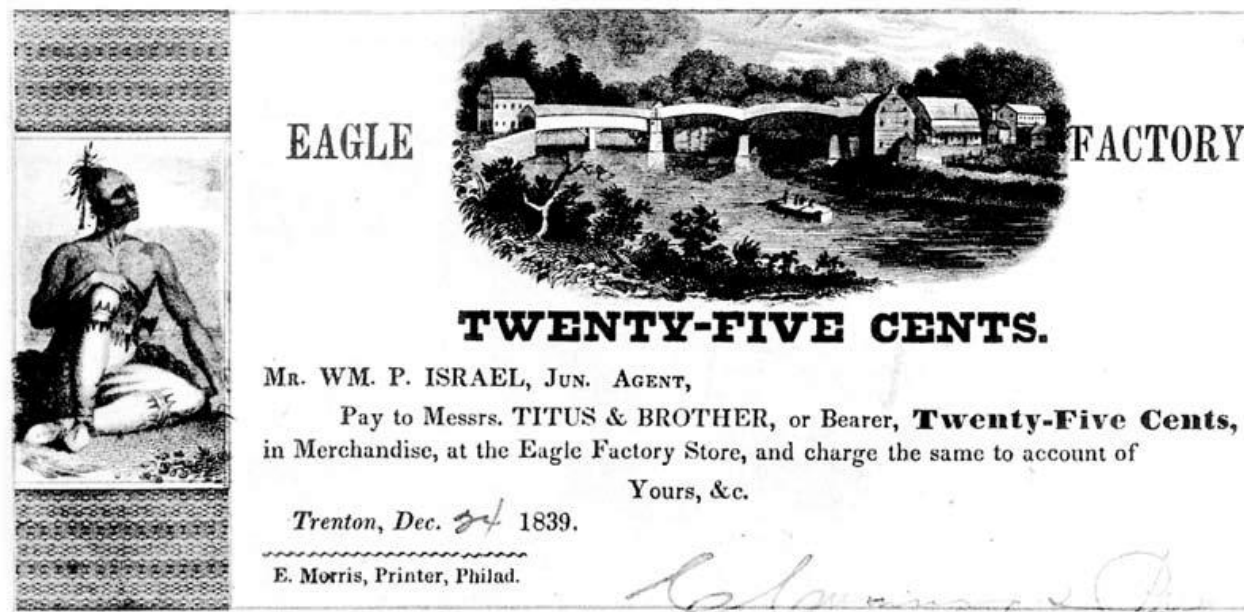

Mr. WM. P. ISRAEL, Jun. Agent,

Pay to Messrs. TITUS \& BROTHER, or Bearer, Twenty-Five Cents, in Merchandise, at the Eagle Factory Store, and charge the same to account of

$$
\text { Trenton, Dec. of } 1839 .
$$$$
\text { Yours, \&c. }
$$

E. Morris, Printer, Philad.

Figure 13. An example of a scrip note issued during the depression of 1837-41 by the Eagle Factory to customers of good standing (George W. Wait, New Jersey's Money [Newark Museum, Newark, New Jersey, 1976], 347, \#2308).

Lewis Waln may even have been contemplating shutting down the mills. A despairing Wells wrote to Waln on September 29, 1829:

I was in hopes after what had passed at Trenton, I should have been informed what was the final determination of W \& L [Waln \& Leaming] as to the business here - I then stated to you my willingness to deliver to them as fast as possible all the Goods here, and to work up the stock on hand, provided they would furnish me with the means to do it.

Wells goes on to indicate that his intention is to leave Trenton altogether, noting that his "situation is too hopeless for me to expect ever to retrieve it here and I am therefore desirous of trying what can be done elsewhere ....to make an effort to better myself."

Lewis Waln, in the guise of Waln \& Leaming, wrote to Charles Wells on the same day (responding to an earlier letter) and proposed inserting his own brother William into the management of the factory, forwarding goods to Philadelphia "as fast as manufactured" and imposing a much tighter grip on the accounting procedures. ${ }^{109}$ This was all to no avail; Wells soon after sold his interest in the factory to Waln ${ }^{110}$ and disappeared from the scene. Clearly there was a major rupture in the management and operation of the Eagle Factory during the summer and late fall of 1829 , which led to a permanent severing of the Waln-Wells longtime partnership in this well-established Trenton business. Lewis Waln's rift with Charles Wells also appears to coincide with the departure of Charles's father, Gideon, from Trenton. Charles's fate is unclear, but prior to his death in 1836, Gideon

\footnotetext{
${ }^{108}$ Charles Wells to Lewis Waln, September 29, 1829, Waln Collection, Historical Society of Pennsylvania.

${ }^{109}$ Waln \& Leaming to Charles Wells, September 29, 1829, Waln Collection, Historical Society of Pennsylvania.

${ }^{110}$ Lewis Waln Letter Book, November 11, 1829, 247 [R. Jackson]; Burlington County Deeds L-563, Y2449, Y2-453.
} 
resurfaced in New York City as a commission agent dealing in cotton goods and as a partner in the firm of Wells \& Spring. ${ }^{111}$ In closing the door on fifteen years of Waln \& Wells business activity, one cannot help but note the "like father, like son" aspects of the Robert Waln/Gideon Wells and Lewis Waln/Charles Wells partnerships, both of which appear to have foundered on the financial and management shortcomings of the Wellses, helped along by the volatile nature of the manufacturing industry.

Following the removal of Charles and Gideon Wells from the Eagle Factory in 1829-30, Lewis Waln appears to have relied heavily on his brother William to oversee the mills. As late as December 1835, "the property at Trenton" is referenced in Lewis Waln's correspondence as being "in charge of my brother." 112 In the late summer and fall of 1831, Lewis was in pursuit of William Hines of Sandy Hill, New York, to come and work as a factory superintendent, but it is uncertain if Hines ever actually signed on for this position. ${ }^{113}$ It is unclear who was managing and supervising the mills in the late 1830s and early 1840s, but, by March of 1842, William P. Israel, one of Lewis Waln's nephews, was filling this role. In the spring of 1842, Israel was engaged on his uncle's behalf in Trenton trying to rent out parts of the mill property, including the lower story of the old gristmill building to a maker of farm implements. It does appear that part of the gristmill was eventually rented from April, 1842 to July 1, 1843 to Robert Stedman, although it is unclear if he was a farm implement maker. ${ }^{114}$ The critical point here is that there was some reduction in the Eagle Factory's use of this building, perhaps indicating a retrenchment of the textile manufacturing operations.

The economic health of the Eagle Factory in the 1830s and early 1840s is difficult to ascertain. In 1833, Lewis Waln reported a capital investment of $\$ 169,000$ in the business, the highest in any cotton factory in New Jersey, including several in Paterson, but the Eagle Factory ranked only tenth in the state in level of output, on a par with the neighboring Trenton Manufactory of James Hoy. ${ }^{115}$ The mills appear to have remained in operation despite the severe economic downturn of 1837-43 and rising competition from other textile facilities in Trenton, all of which drew their water power from the newly built canal of the Trenton Delaware Falls Company (Figure 4). The Eagle Factory was not in a position to draw water power from this canal, but Hoy's cotton mill was reconfigured in 1834-35 to do just this, and relinquished all claim to the water power previously leased from the Walns and Wellses. ${ }^{116}$

With the new mill construction in downtown Trenton in the 1830s and 1840s, water power was at a premium on the Lower Assunpink, and Lewis Waln appears to have been carefully guarding his own interests in this regard. In 1835, he was in contact with Robert

\footnotetext{
${ }^{111}$ Lewis Waln Letter Book, December 9, 1830, 254 [Garrett D. Wall]; March 13, 1835, 285 [Gideon Wells].

${ }^{112}$ Lewis Waln Letter Book, December 26, 1835, 292 [John Travers].

${ }^{113}$ Lewis Waln Letter Book, August 16 and 30, 1831, 259-260, October 11, 1831, 262 [W. Hines].

${ }^{114}$ William H. Plummer to Lewis Waln, March 5, 1842; William Dickinson to Lewis Waln, April 4, 1842 , Waln Collection, Historical Society of Pennsylvania; Lewis Waln Letter Book, April 5 and April 29, 1842, 355-356 [P. Dickinson].

${ }^{115}$ McLane, Documents Relative to the Manufactures in the United States, 168-169.

${ }^{116}$ Lewis Waln Letter Book, March 13, 1835, 285 [Gideon Wells].
} 
Stockton, president of the Delaware and Raritan Canal Company, concerning the effects of the canal's crossing of the Assunpink, upstream of the Eagle Factory, on his own property and water rights. ${ }^{117}$ Waln even had plans, apparently unrealized, to form a company to draw off surplus water from the canal into the Assunpink for water power usage. ${ }^{118}$ In 1839, he was repelling claims from other creek-side property owners of damage from his own water usage on the Assunpink. ${ }^{119}$ Ultimately, the increasing intensity of mill development and industrial water power usage downtown, which reached a peak in the mid nineteenth century, along with the inexorable outward spread of urban Trenton, greatly increased the susceptibility of the Assunpink to flooding, another factor that was to hasten the demise of the Eagle Factory.

In January of 1843, just as the national economy was beginning to show signs of rebounding, the Eagle Factory experienced the first in a series of setbacks when a fire consumed the cotton storehouse, a building on the south bank of the creek that had previously functioned as the carting house. ${ }^{120}$ Not long after, during the week of March 27, a rain and thaw "caused a great freshet in the Assunpink" which wrought considerable damage not only to the gristmill, weaving mill and store on the south bank of the creek, but also to the mill raceways and Greene Street bridge. ${ }^{121}$ As noted earlier, the March flood was followed by a July drought which caused the factory to shut down for several weeks in midsummer. ${ }^{122}$

The travails of 1843 undoubtedly placed a burden on the Eagle Factory's economic viability. In June of 1844, William Israel wrote to Lewis Waln that "the profits are not as large as I anticipated [and] the interest account is unusually large." ${ }^{123}$ Israel soldiered on, superintending the mills through the rest of the year, with no indication being given that that the business was in danger of imminent failure. Then, on the morning of January 10, 1845, a devastating fire consumed the main factory building, destroying all the machinery contained inside, and closing the mills. Some 50 employees lost their jobs, although 30 of them found work at James Hoy's cotton factory next door. Lewis Waln filed a claim for $\$ 10,000$ with the Franklin Fire Insurance Company, the amount for which the factory was insured, noting that the value of the machinery destroyed far exceeded this figure. ${ }^{124}$

Lewis Waln chose not to rehabilitate the building and instead put the entire Eagle Factory site on the market. A public sale was organized for April 10, but no reasonable offers were forthcoming. ${ }^{125}$ Waln received further inquiries in the weeks following, but his

\footnotetext{
${ }^{117}$ Lewis Waln Letter Book, March 27, 1835, 286 [Robert Stockton].

${ }^{118}$ Lewis Waln Letter Book, September 5, 1835, 289 [Robert Stockton].

${ }^{119}$ Lewis Waln Letter Book, May 30, 1839, 338 [William Halstead].

${ }^{120}$ William P. Israel to Lewis Waln, January 16, 1843, Waln Collection, Historical Society of

Pennsylvania.

${ }^{121}$ State Gazette, March 30, 1843; Raum, A History of the City of Trenton, 169, 171.

${ }^{122}$ William P. Israel to Lewis Waln, March 29, 1843, April 6, 1843, July 8, 1843, July 18, 1843, August 17, 1843, Waln Collection, Historical Society of Pennsylvania.

${ }^{123}$ William P. Israel to Lewis Waln, June 13, 1844, Waln Collection, Historical Society of Pennsylvania.

${ }^{124}$ Lewis Waln Letter Book, January 11, 1845, 380 [Charles Bancker]; State Gazette, January 13, 1845.

${ }^{125}$ Lewis Waln Letter Book, March 10, 1845, 383 [James R. Mills]; March 31, 1845, 384 [P. Dickinson]; April 11, 1845, 384 [Lloyd Wells].
} 
asking price of $\$ 45,000$ and the fact that the property was still subject to a $\$ 20,000$ mortgage likely deterred potential buyers. ${ }^{126}$ Two years later, the Eagle Factory estate still remained unsold, despite a reduced asking price of $\$ 30,000 .{ }^{127}$ In the interim, Waln rented parts of the property to ensure at least a modicum of income from this expensive urban asset, and it is interesting to note that he also negotiated an arrangement to lease water power again to James Hoy. ${ }^{128}$ In early 1846, yet another fire struck, this time damaging the old stone gristmill. Waln subsequently decided to demolish the walls down to "the level of the top of the wall of the bridge." 129

Throughout the late 1840s, the Eagle Factory estate must have been a veritable Trenton millstone around Lewis Waln's Philadelphia neck. The property had been ravaged by fires and floods, and was difficult to rent or sell. Waln feuded frequently with his neighbors, including the Trenton Water Power Company, over water rights, flood damage and boundary delineations. ${ }^{130} \mathrm{He}$ was also burdened with a $\$ 20,000$ mortgage on a tract of land and several aging buildings that were generating very little financial return. Finally, in 1849, Lewis Waln found a buyer in Henry McCall, Jr., who acquired the entire estate, which corresponded to virtually all of the original 29-acre mill tract that had been owned by Robert Waln, Sr. two generations earlier (Figure 14). ${ }^{131}$ McCall erected a paper mill on the site of the old gristmill, and, in 1852, sold the site of the main Eagle Factory cotton mill building west of Greene Street to William Stetler and William Hancock, who set up a soap and candle manufactory. ${ }^{132}$ Lewis Waln, undoubtedly exhausted from his three-decade Trenton venture, lived out the remainder of his life at Waln Grove, the family estate outside Philadelphia, where he died in 1863.

\section{Conclusion}

Certainly Trenton's textile industry, and specifically the Eagle Factory, fell victim to broad economic trends, but there were other reasons that the city's cotton mills, woolen factories and print works fell idle. In the era immediately before coal-fired steam power became the industrial energy norm, increasingly sophisticated textile manufacturing processes required substantial and reliable sources of water power. Simply put, Trenton could not be hydro-engineered to the level of a Paterson or a Lowell. The Assunpink Creek was barely sufficient to power the Eagle complex, while the Trenton Delaware Falls Company's power canal, expensive to build and maintain, attracted less mill development than anticipated. Periodic, serious flooding along the Assunpink and Delaware only compounded these limitations on water-powered industrial development

\footnotetext{
${ }^{126}$ Lewis Waln Letter Book, April 21, 1845, 385 [J.M. Redmond]; May 15, 1845, 386 [A. Goodwin].

${ }^{127}$ Lewis Waln Letter Book, March 15, 1847, 402, June 4, 1847, 404 [Thomas Stryker].

${ }^{128}$ Lewis Waln Letter Book, March 10, 1846, 395, March 15, 1847, 402 [Thomas Stryker].

${ }^{129}$ Lewis Waln Letter Book, March 10, 1846, 395 [Thomas Stryker].

${ }^{130}$ Lewis Waln Letter Book, September 11, 1845, 388; January 15, 1847, 399; January 19, 1847, 400-401; January 23, 1847, 401.

${ }^{131}$ Mercer County Deed P-399.

${ }^{132}$ Mercer County Deed Z-18.
} 


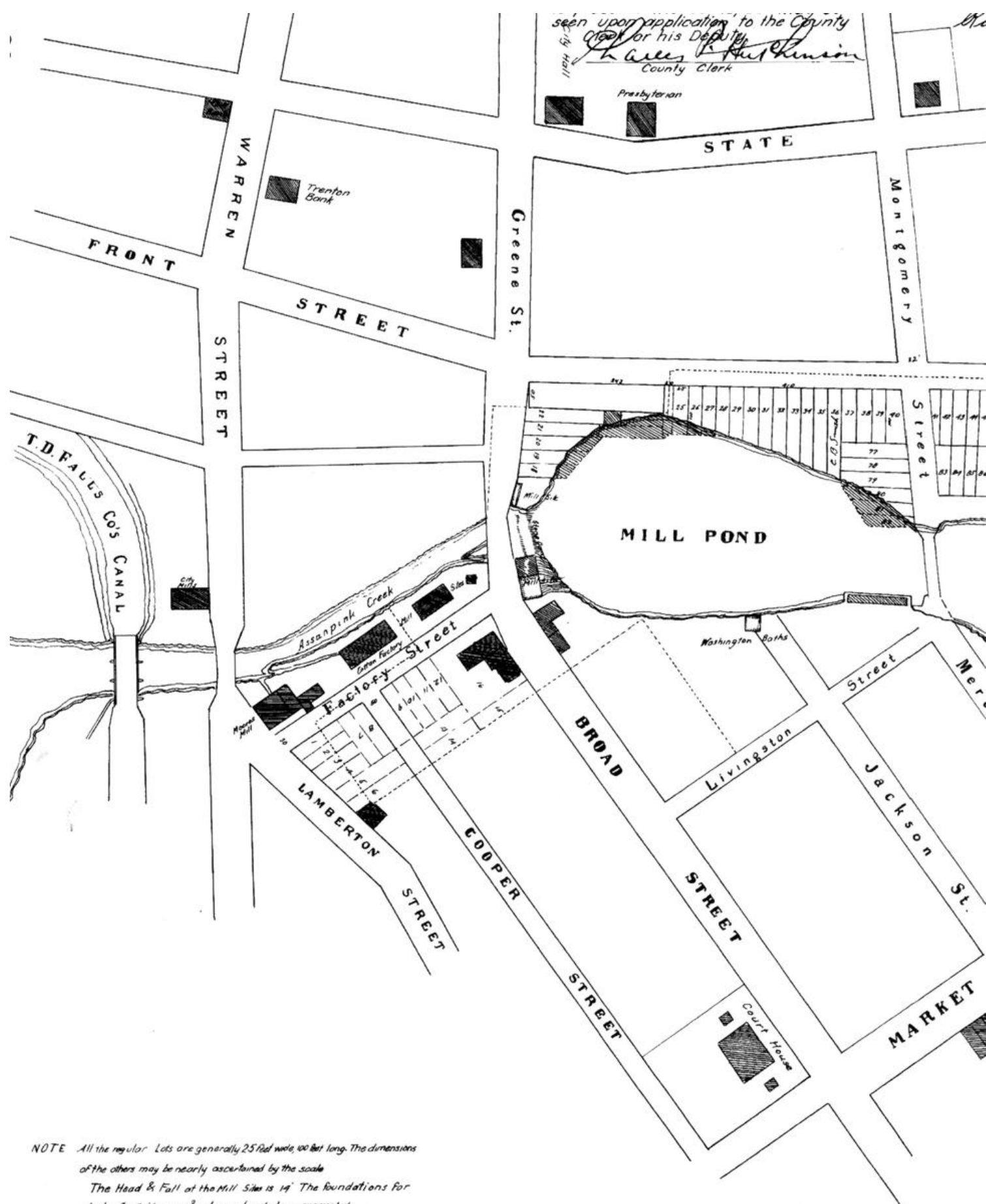

Figure 14. Charles Potts. Property of Henry McCall, Jr. 1849. Scale 1 inch: 260 feet (approximately).

in the city. Furthermore, Trenton, unlike Lowell and Paterson, did not have a blank canvas upon which to lay out its mills and hydrosystem, and instead had to stitch them into a pre-existing urban fabric. Roads, bridges, dwellings and other buildings all placed limits on mill and raceway siting. 
As this brief history of the Eagle Factory shows, the growth of Trenton's textile industry in the early nineteenth century was hindered by its organizational structure.

The Eagle Factory operated essentially along the lines of the "Slater system" with strong family involvement in the management of the mills. On at least two occasions (in 18191821 and in 1829-1830), family tensions between the Walns and the Wellses over financial matters, along with apparent management failings on the part of Gideon and Charles Wells, severely disrupted Eagle Factory business. Neither the Eagle Factory, nor any of the other Trenton textile mills, fully rose to the level of the more evolved, corporate-based Waltham-Lowell system of operation.

Trenton's overall industrial prospects improved and changed dramatically in character in the mid nineteenth century as water power began to decline in importance as a fuel for industrial growth. The city's subsequent industrial prosperity was founded more on its regional transportation advantages, and specifically its accessibility by canal and rail, which allowed for easy import of coal, iron and clay, and distribution of metal and pottery products. Yet Trenton's foray into cotton textile manufacture constituted the city's first steps toward recognizing its industrial potential. Admittedly, the Eagle did not soar as magnificently as the Walns perhaps hoped, but its flight was nevertheless a pioneering venture worthy of remembrance as a significant episode in Trenton's rich industrial history. 
Hunter, Sergejeff and Tvaryanas 